\title{
Abridged Life Tables for Registered Indians in Canada, 1976-1980 to 1996-2000
}

\author{
Ravi B.P. Verma, \\ Margaret Michalowski \\ Statistics Canada \\ Ottawa, Ontario, Canada. \\ R. Pierre Gauvin \\ Department of Indian Affairs and Northern Development (DIAND) \\ Ottawa, Ontario, Canada
}

\begin{abstract}
This paper presents the analyses of the new estimates of abridged life tables comprising life expectancy at birth, and their estimates of variance and confidence limits by males and females for Registered Indians in Canada and two broad regions (East: Atlantic, Quebec, Ontario, and Manitoba; and West: Saskatchewan, Alberta, British Columbia, Yukon and Northwest Territories) for the periods, 1976-80, 1981-1985, 1986-1990, 1991-1995 and 1996-2000. The life tables were constructed using the Chiang Method based on the adjusted data on deaths and population by age and sex from the Indian Registry, maintained by the Department of Indian Affairs and Northern Development, Government of Canada. The data on the register are subjected to late reported and non reported vital events. At the Canada level, life expectancy at birth for Registered Indian males was 59.9 years in 1976-1980, rising to 68.3 years in 1996-2000. For females, the life expectancy at birth was relatively higher, 66.6 years in 1976-80, and 74.5 years in 1996-2000. The recent life expectancies at birth for Registered Indians are comparable to those observed for the total Canadian male and female populations during the period 1960-1962 at 68.4 and 74.3 years. In 1999 , life expectancy at birth for the total Canadian population was reported to
\end{abstract}


Ravi B. P. Verma, Margaret Michalowski and R. Pierre Gauvin

be 76.3 years for males and 81.7 years for females. The life expectancy at birth for the Registered Indians in the Eastern region was higher than for those in the Western region. The pattern of regional variation in life expectancy at birth for this population seems to be the reverse of the regional variation for the total Canadian population.

Key Words: life tables, variance and confidence limits of life expectancy, Registered Indians

\section{Résumé}

Ce document présente les analyses des nouvelles estimations des tables de survie abrégées comprenant l'espérance de vie à la naissance, l'estimation de leur variance et la limite de confiance selon le sexe pour les Indiens inscrits au Canada et dans 2 grandes régions (Est: Atlantique, Québec, Ontario et Manitoba; et Ouest : Saskatchewan, Alberta, Colombie-Britannique, Yukon et Territoires du Nord-Ouest) pour les périodes 1976-80, 1981-1985, 1986-1990, 1991-1995 et 1996-2000. Les tables de survie ont été construites avec la méthode de Chiang s'appuyant sur les données rajustées des décès et la population par âge et sexe provenant de l'Inscription des Indiens, tenu à jour par le ministère des Affaires indiennes et du Nord canadien, gouvernement du Canada. Les données de l'inscription sont sujettes aux déclarations tardives et aux non déclarations des événements démographiques. Au niveau national, l'espérance de vie à la naissance pour les hommes Indiens inscrits était de 59,9 ans en 1976-1980, s'élevant à 68,3 ans en 1996-2000. Pour les femmes, l'espérance de vie à la naissance était relativement plus élevée, soit 66,6 ans en 1976-1980 et 74, 5 ans en 1996-2000. Les espérances de vie à la naissance récentes des Indiens inscrits sont comparables à celles observées pour l'ensemble de la population hommes et femmes du Canada pendant la période 1960-1962 à 68,4 et 74,3 ans. En 1999, l'espérance de vie à la naissance pour l'ensemble de la population canadienne était de 76,3 ans pour les hommes et de 81,7 ans pour les femmes. L'espérance de vie à la naissance pour les Indiens inscrits dans la région de l'est était plus élevée que celle de la région de l'ouest. Le modèle des écarts régionaux dans l'espérance de vie à la naissance pour cette population semble être l'inverse des écarts régionaux de l'ensemble de la population canadienne.

Mots Clés - table de survie, variance et limite de confiance de l'espérance de vie, Indiens inscrits 
Abridged Life Tables for Registered Indians in Canada,

1976-1980 to 1996-200

\section{Introduction}

Life expectancy at birth is one of the best indicators for assessing improvements in mortality trends and health conditions of the human population. Since 1921, Statistics Canada has usually published life tables for the general Canadian population (Nagnur, 1986). Over the last two decades, Statistics Canada has also developed life tables for the Registered Indian population as defined by the Indian Act. This was one of the activities leading to the production of projections of the Registered Indian population done in collaboration with the Department of Indian Affairs and Northern Development (DIAND). In 1985, life tables for Registered Indians for the periods 1976 and 1981 were produced (Norris and Rowe, 1985, Loh, 1990). In 1993, these life tables were updated and extended to the period 1975 to 1991 (Nault, et al. 1993). These were later modified and extended up to 1995 (Loh, et al. 1998). In all these life tables, data on deaths and population by age and sex for Registered Indians were adjusted to account for late reported and never reported vital events which are very common in the Indian Registry data. These previous life tables were constructed using the Brass method (1964). A number of indirect techniques were used to adjust these data at the Canada and region levels (Verma, et al. 1999). These vital events might not have been fully adjusted. As a consequence, based on the previous series of life tables, it is difficult to determine the actual changes in levels of mortality. In view of this, the life tables and variances of life expectancy at birth were produced using the Chiang Method (1984) for the Registered Indian population using the most updated series of vital events and population by age and sex for the years, 1976-80, 1981-1985, 1986-1990, 1991-1995 and 19962000 .

This paper presents the temporal analyses over the $1976-2000$ period of the recently revised estimates of life expectancy at birth (their variance and confidence limits) among Registered Indians in Canada, and for two broad regions, East and West. Due to the small number of cases of age specific deaths among Registered Indians by smaller geographic areas, it was decided to construct the life tables for the two regions representing low and high mortality levels. The East region includes the Atlantic provinces, Quebec, Ontario and Manitoba while the West region covers British Columbia, Alberta, Saskatchewan, Yukon and Northwest Territories. The life tables for Registered Indians were constructed using adjusted data on deaths and population which were developed in 2002 as part of the production of their population projections by age and sex from 2000 to 2021 for the DIAND (Statistics Canada, 2002); and life tables for the total Canadian population were taken from vital statistics section of Health Division, Statistics Canada. The paper begins by addressing 
Ravi B. P. Verma, Margaret Michalowski and R. Pierre Gauvin

the quality of data on deaths, births and population from the Indian Registry. Then, it discusses the methods for adjusting these data due to late reporting and never reporting of events. Thereafter, it presents the methodology for constructing the abridged life tables, the variances and confidence limits of life expectancy at birth using the Chiang method. Finally, it compares life expectation at birth $\left(\mathrm{e}_{0}\right)$ between the Registered Indians and the total Canadian population. Although it is expected that $\mathrm{e}_{0}$ has increased considerably for both populations, given the historically lower socio-economic status of Registered Indians ${ }^{1}$, the $\mathrm{e}_{0}$ for Registered Indians would remain below the total Canadian population level. Since there is a greater proportion of the Registered Indian population living in territories in Canada which might have more difficult access to health care facilities, one could assume that the mortality levels (lower expectancy of life at birth) would be higher in the Western region than in the Eastern/central region.

\section{Evaluation and Adjustment of Vital Events, 1973-2000}

Basically, the methodology for generating adjusted time series on births, deaths and population from 1973 to 2000 involved three steps (Verma, et al. 1999). First, the previously adjusted 1973-1998 time series data on births and deaths were updated on the basis of additional information on the late-reported events. Second, adjustments for the events that had not yet been reported, but would be reported after 2000 were done. Third, population data by age and sex were adjusted by taking into account the above two adjustments of births and deaths.

Since births are classified by year of reporting and year of occurrence, it is possible to measure the length of reporting delays. An examination of time series data on births indicates that births continue to be reported up to 18 years after their occurrence. On the basis of more recent data pertaining to latereported events, previously adjusted time series data on births from 1973 to 1998 were re-adjusted for late reporting, and then updated to 2000. Reallocating the late-reported births that were reported between 1998 and 2000 to the year of occurrence and merging these births with the previously adjusted time series provided the adjustment for late reporting. The adjustment for underreporting was done by taking account of the cases where a baby died before its birth was recorded in the Register. In these cases, the event is neither reported as a birth nor as a death. Based on the Brass technique, infant mortality rates were estimated to derive the unreported births (Loh, et al. 1998).

In a similar manner to the time series data on births, the previously adjusted time series data on deaths for 1973 to 1998 were updated with new information on actual late-reported events that were reported between 1998 and 2000. A ratio 
approach was used to adjust for the not-yet-reported deaths. Since almost all the deaths are reported within 5 years of their occurrence, the ratio method was applied up to a lag of 5 years. The average age and sex distribution of latereported deaths over the last 3 years of observation (1998-2000) was used to distribute the estimated not-yet-reported deaths by age and sex. The death data series were further adjusted for underreporting. The infant mortality rates among the Registered Indians were unusually low when compared with the Canadian rates. Moreover, an examination of the adjusted population data by age and sex incorporating the effects of adjusted births and deaths showed an exceptionally large number of very old people. The Brass model (Brass, 1968) was used to estimate the level of the underreporting of deaths among the Registered Indians for ages 0 and $65+$. Adjustment factors from $3 \%$ to $10 \%$ with the annual interval of 0.25 over the years 1972-2000 were applied to deflate the adjusted elderly population aged $65+$ due to the late-reported and underreporting of vital events. As the results, the total numbers of elderly over the period 1972 to 2000 were deflated by 1,415 for males, and 1,962 for females at the Canada level. These numbers were included in the fully adjusted deaths.

Using the above fully adjusted estimates of births and deaths, the population data by age from the Indian Register were modified separately for males and females.

The adjusted Registered Indian population for 2000 was about 699,000 compared with 675,500 in the Register, (a difference of $2.14 \%$ ). The adjustments affected mostly the ages at both ends of the age spectrum. (Verma, et al. 2001). The majority of adjustments for late reporting of births occurs for the population under age five. By the time individuals enter the school system, most are listed in the Indian Register. For instance, we have adjusted the population under age 1 by around 10,000 (from 4,800 to 15,055 ; or by over $70 \%$ ). For deaths, an adjustment was made to remove individuals who were assumed to be deceased, but had not yet been removed from the Indian Register (There is no legal requirement to report a death in the Indian Register). In 2002, this adjustment represented a removal of about $10 \%$ of the population aged 65 and over from the Indian Register.

\section{Methods for Construction of Life Tables and Variance Components}

In the past, life tables for Registered Indians were constructed by using the Brass method (Brass, 1964). This method is based on a two-parameter model of a life table system. According to this method, if one sets $1_{0}=1$ and $1 \mathrm{w}=0$, then $1 \mathrm{x}$ will fall between 0 and 1 for each age $\mathrm{x}$ and $\mathrm{lx}$ is a decreasing function of $\mathrm{x}$, for 0 to 
Ravi B. P. Verma, Margaret Michalowski and R. Pierre Gauvin

$\mathrm{w}$. He then expresses the logit of $1 \mathrm{x}$ as a linear function of $\mathrm{X}$ to determine $1 \mathrm{x}$. The equation is given below:

$$
\log \left(1-1_{x}\right) / 1_{x}=a+b X
$$

where

$1_{x}$ values are for the Registered Indians;

$\mathrm{X}$ values are for $l_{\mathrm{x}}$ from the standard life table (such as nation as a whole);

$a$ and $b$ are constants of the linear relationship.

In the Brass method, logits are used to smooth the life table function when information is distorted. In the past, this method was found to be a practical approach for constructing life tables using the adjusted death and population data for the Registered Indian population. However, Chiang's method (1984) is much simpler. This method has been used by Statistics Canada in analyzing the differences in life expectancy among health regions in Canada (Gilmore, 1999) and does not require the application of the standard life table.

The Chiang method for the construction of life tables uses the values of $a_{0}$ (fraction of last age interval of life). When a person dies at age 23, for example, this person has lived through a certain fraction of the age interval (20-25). The average fraction lived in each interval $(x i, x i+1)$ is called the fraction of the last age interval of life. It depends on the probability of dying and the corresponding fraction of last year of life ax for each year of age within the interval (Chiang, 1984, Table 3, page 143).

The direct computation of $\mathrm{a}_{0}$ requires an extensive set of detailed data on deaths by age interval at death. Such data for the Registered Indian population cannot be tabulated easily. Hence, it was decided to use the guideline of the World Health Organization (WHO) for selecting the value of $\mathrm{a}_{0}$ (Chiang, 1984:144). The value of $\mathrm{a}_{0}$ varies with the infant mortality rate of a population.

Verma et al (2001) have computed infant mortality rates for the Registered Indian population from 1972-1975 to 1996-2000. Table 1 shows the infant mortality rates for the Registered Indians for Canada and two regions, East and West; and for the total Canadian population at the Canada level only.

For example, on average, the infant mortality rate for Registered Indians at the Canada level was 30.7 per 1,000 live births in 1976-1980. The infant mortality rate for Registered Indians in the Eastern region was lower than the Western region (25.1 vs 35.9 per 1,000 live births respectively). By 1996-2000, the infant mortality rate for Registered Indians declined to 9.4 per 1,000 live births at the 
Abridged Life Tables for Registered Indians in Canada,

1976-1980 to 1996-200

\begin{tabular}{lc}
\hline Infant mortality rate per 1,000 live births & Value of $\mathbf{a}_{\mathbf{0}}$ \\
\hline \hline Less than 20 & .09 \\
$\mathbf{2 0 - 4 0}$ & .15 \\
$\mathbf{4 0 - 6 0}$ & .23 \\
Greater than 60 & .30 \\
\hline
\end{tabular}

Canada level. At the regional level, the infant mortality rates declined to 8.2 and 10.5 per 1,000 live births in the Eastern and Western regions respectively. Therefore, in order to construct the abridged life tables for Registered Indians, we have used the values of $\mathrm{a}_{0}$ between 0.09 to 0.15 . For each period, the infant mortality rates for the total Canadian population are much lower over those for the Registered Indians. However, the rate of decline in the infant mortality rates for the latter group has been much faster than that of the former group.

Table 1

Infant Mortality Rates (Adjusted) per 1,000 Live Births for Registered Indians and Canadian Population for Canada and Two Broad Regions, East and West, 1972 to 2000

\begin{tabular}{ccccc}
\hline Period & \multicolumn{3}{c}{ Registered Indians } & $\begin{array}{c}\text { Canadian } \\
\text { Population }\end{array}$ \\
& East & West & Canada & \\
\hline & & & & \\
$\mathbf{1 9 7 2 - 1 9 7 5}$ & 35.5 & 45.3 & 40.4 & 14.2 \\
$\mathbf{1 9 7 6 - 1 9 8 0}$ & 25.1 & 35.9 & 30.7 & 11.7 \\
$\mathbf{1 9 8 1 - 1 9 8 5}$ & 19.0 & 24.3 & 21.5 & 8.6 \\
$\mathbf{1 9 8 6 - 1 9 9 0}$ & 9.3 & 13.9 & 11.7 & 7.3 \\
$\mathbf{1 9 9 1 - 1 9 9 5}$ & 8.4 & 12.4 & 10.4 & 6.2 \\
$\mathbf{1 9 9 6 - 2 0 0 0}$ & 8.2 & 10.5 & 9.4 & 5.4 \\
& & & & \\
\hline
\end{tabular}


Ravi B. P. Verma, Margaret Michalowski and R. Pierre Gauvin

Table 2 shows a complete set of the fraction of last age interval of life, $a_{i}$, for the Registered Indian population, 1976-80 to 1996-2000.

The values of the different columns of the abridged life tables were calculated using the following formulae:

Age-specific death rate

$\mathrm{Mi}=\mathrm{Di} / \mathrm{Pi}$

where $\mathrm{Di}$ and $\mathrm{Pi}$ are the number of deaths and the mid-year population for the age interval

$\left(\mathrm{x}_{\mathrm{i}}\right.$ and $\left.\mathrm{x}_{\mathrm{i}+1}\right)$,

Proportion of dying in age interval $\left(\mathrm{x}_{\mathrm{i}}, \mathrm{x}_{\mathrm{i}+1}\right)$

qi $\quad=\quad\left(n_{\mathrm{i}} \mathrm{M}_{\mathrm{i}} /\left(1+\left(1-\mathrm{a}_{\mathrm{i}}\right) \mathrm{n}_{\mathrm{i}} \mathrm{M}_{\mathrm{i}}\right)\right)$

where $n_{i}$ is the interval of ith age group and $a_{i}$ is the fraction of last age interval of life

Number of deaths at exact age

$$
\mathrm{d}_{\mathrm{i}}=\quad \mathrm{l}_{\mathrm{i}} \mathrm{q}_{\mathrm{i}}, \mathrm{i}=0,1 \ldots 85+
$$

Number of living at age $\mathrm{x}_{\mathrm{i}+1}$

$$
\mathrm{l}_{\mathrm{i}+1}=\quad \mathrm{l}_{\mathrm{i}}-\mathrm{d}_{\mathrm{i}}
$$

Number of years lived in age interval $\left(\mathrm{x}_{\mathrm{i}}, \mathrm{x}_{\mathrm{i}+1}\right)$

$$
\begin{array}{ll}
\mathrm{L}_{\mathrm{i}}= & \mathrm{n}_{\mathrm{i}}\left(\mathrm{l}_{\mathrm{i}}-\mathrm{d}_{\mathrm{i}}\right)+\mathrm{a}_{\mathrm{i}} \mathrm{n}_{\mathrm{i}} \mathrm{d}_{\mathrm{i}}, \mathrm{i}=0,1, \ldots 84 \\
\mathrm{~L}_{85+}= & \mathrm{l}_{85+} / \mathrm{M}_{85+},
\end{array}
$$

Total number of years to be lived by individuals attaining age $x_{i}$

$$
\mathrm{Ti}=\mathrm{Li}+\mathrm{II}+1 \ldots+\mathrm{L} 85+
$$


Abridged Life Tables for Registered Indians in Canada, 1976-1980 to 1996-200

Table 2

Fraction of Last Age Interval of Life, $a_{i}$, for Registered Indian Population used for 1976-80 to 1996-2000

\begin{tabular}{|c|c|c|c|c|c|}
\hline $\begin{array}{c}\text { Age } \\
\text { Interval }\end{array}$ & 1976-80* & 1981-85* & $1986-90 * *$ & $1991-96 * *$ & $1996-00 * *$ \\
\hline $0-1$ & 15 & 15 & .09 & 09 & .09 \\
\hline $1-4$ & .39 & .39 & .41 & .41 & .41 \\
\hline $5-9$ & .47 & .47 & .44 & .44 & .44 \\
\hline $10-14$ & .55 & .55 & .54 & .54 & .54 \\
\hline $15-19$ & .56 & .56 & .59 & .59 & .59 \\
\hline $20-24$ & .50 & .50 & .49 & .49 & .49 \\
\hline $25-29$ & .51 & .51 & .51 & .51 & .51 \\
\hline $30-34$ & .53 & .53 & .52 & .52 & .52 \\
\hline $35-39$ & .53 & .53 & .53 & .53 & .53 \\
\hline $40-44$ & .53 & .53 & .54 & .54 & .54 \\
\hline $45-49$ & .54 & .54 & .53 & .53 & .53 \\
\hline $50-54$ & .52 & .52 & .53 & .53 & .53 \\
\hline $55-59$ & .53 & .53 & .52 & .52 & .52 \\
\hline $60-64$ & .52 & .52 & .52 & .52 & .52 \\
\hline $65-69$ & .52 & .52 & .51 & .51 & .51 \\
\hline $70-74$ & .51 & .51 & .52 & .52 & .52 \\
\hline $75-79$ & .50 & .50 & .51 & .51 & .51 \\
\hline $80-84$ & .48 & .48 & .50 & .50 & .50 \\
\hline $85+$ & .45 & .45 & .47 & .47 & .47 \\
\hline
\end{tabular}

Notes: * the values of $\mathrm{a}_{\mathrm{i}+1}$ are taken from Appendix Table 6, France 1969 with respect to $\mathrm{a}_{0}$ equal to .15 .

**the values of $\mathrm{a}_{\mathrm{i}+1}$ are taken from Appendix Table 2, California, 1970. 
Expectation of life at age $x_{i}$

$$
\mathrm{E}_{\mathrm{i}}=\mathrm{Ti} / \mathrm{li}
$$

In each age interval, the estimates of the probability of death and the probability of survival are complements of one another, $\mathrm{pi}=1$-qi. Therefore, they have the same sample variance.

The formulas for the variance and the standard error of survival/death and expectation of life at birth are given below:

$$
S_{\hat{P} i}^{2}=\frac{\hat{q}_{i}^{2}\left(1-\hat{q}_{i}\right)}{D_{i}}
$$

Where $\mathrm{Di}$ is the adjusted number of deaths in age interval $(\mathrm{xi}, \mathrm{xi}+1)$

A computation of the standard error of the expectation of life at birth was done in the following steps:

-Compute for each age interval this element:

$$
l_{i}^{2}\left[\left(1-a_{i}\right) n_{i}+\hat{e}_{i+1}\right]^{2} S_{\hat{P}_{i}}^{2}
$$

-Sum the products from the bottom of the table up to Age X

$$
\sum_{j \geq i} l_{i}^{2}\left[\left(1-a_{i}\right) n_{i}+\hat{e}_{i+1}\right]^{2} S_{P_{i}}^{2}
$$

- Divide the sum from the previous step by square of li to obtain the sample variance of the observed expectation of life;

-Take the square root of the variance to obtain the standard error of the expectation of life

For Registered Indians, the data on fully adjusted deaths were developed by age groups $(0,1-4,5-9 \ldots 65+)$ for Canada and two broad regions, Eastern and Western from 1973 to 2000 . In order to construct abridged life tables, the deaths among the elderly population aged $65+$ years were broken down further up to age $85+$ based on the time-lagged distribution of deaths among the elderly 
Canadian population taken from the Canadian historical life tables (Nagnur, 1986). We have used the following Canadian historical life tables: the 1931-32 tables (47 years lag) for the period 1976-80; the 1940-42 tables (42 years lag) for the period 1981-85; the 1950-52 tables (37 years lag) for the period 1986-91; the 1960-62 tables (32 years lag) for the period 1991-95; and lastly, the 1970-72 tables (27 years) for the period 1996-2000.

At the Canada level, the estimates of life expectancy at birth $\left(\mathrm{e}_{0}\right)$ for Registered Indian males and females were generated using the terminal age groups $65+$, $80+, 85+, 90+$ years. The estimated values of $\mathrm{e}_{0}$ by gender for the year 1998 are given below:

Terminal Age Groups

Life Expectancy at Birth $\left(\mathrm{e}_{0}\right)$

Males Females

\begin{tabular}{lll}
\hline \hline & & \\
$\mathbf{6 5}+$ & 69.47 & 77.89 \\
$\mathbf{8 0 +}$ & 67.78 & 73.46 \\
$\mathbf{8 5}+$ & 68.28 & 74.49 \\
$\mathbf{9 0 +}$ & 68.70 & 75.53 \\
\hline
\end{tabular}

Extension of the terminal age group $65+$ to $85+$ years seems to have a considerable impact on the level of life expectancy at birth $\left(\mathrm{e}_{0}\right)$. However, differences in the life expectancy at birth $\left(\mathrm{e}_{0}\right)$ based on the terminal age groups $85+$ and $90+$ are minimal. Hence, it was decided to construct the abridged life tables using age groups, $0,1-4,5-9 \ldots .80-84,85+$.

The Appendix Tables 1 to 15 show the calculation of abridged life tables by gender and their estimates of variances and 95\% confidence limits for Registered Indians for Canada and the two regions, East and West, 1976-1980 to 1996-2000. 


\section{Validation of Estimated Life Expectancy at Birth}

In Table 3, we evaluated the accuracy of the estimated life expectancy at birth for the Registered Indians in two ways. First, we computed the life expectancy for the Registered Indians for the period, 1996-2000 at the Canada level, using the unadjusted deaths and population by age. These estimates of $\mathrm{e}_{0}$ were compared with the estimates of $\mathrm{e}_{0}$ based on the adjusted deaths and population by age. The life expectancy at birth based on the unadjusted deaths and population for males and females were higher by 4 years over the adjustedbased estimates of $\mathrm{e}_{0}$, implying the overestimates of longevity for the Registered Indians. This could be due to never and under-reporting of deaths among Registered Indians. Population estimates without adjustment for deaths and births were also subject to quality problems. So, the lower level of the estimates of $\mathrm{e}_{0}$ based on the adjusted vital events and population for the Registered Indians seem to be a better indicator of their levels of mortality and health.

Table 3

Evaluation of Estimated Life Expectancy at Birth for Registered Indians, Canada, 1996-2000

\begin{tabular}{|c|c|c|c|c|c|}
\hline \multirow{3}{*}{$\begin{array}{l}1996- \\
2000\end{array}$} & \multicolumn{4}{|c|}{ Registered Indians } & \multirow{3}{*}{$\begin{array}{l}\text { Unweighted } \\
\text { Average } \mathrm{e}_{0} \text { * }\end{array}$} \\
\hline & \multirow{2}{*}{\begin{tabular}{|c}
$\begin{array}{c}\text { Unadjuste } \\
\text { d }\end{array}$ \\
$\mathbf{e}_{\mathbf{0}}$
\end{tabular}} & \multirow{2}{*}{$\begin{array}{c}\text { Adjusted } \\
\mathrm{e}_{0}\end{array}$} & \multicolumn{2}{|c|}{$\begin{array}{c}\text { 95\% Confidence } \\
\text { Limits for } \\
\text { Adjusted }\end{array}$} & \\
\hline & & & Lower & Upper & \\
\hline Male & 72.2 & 68.3 & 64.5 & 72.0 & 71.3 \\
\hline Female & 77.8 & 74.5 & 71.0 & 78.0 & 77.1 \\
\hline
\end{tabular}

Second, we compared the adjusted estimates of $\mathrm{e}_{0}$ for the Registered Indian population with the estimates of $\mathrm{e}_{0}$ developed by Gilmore (1999) who identified 12 health regions with the lowest life expectancy at birth (Table 4). These life tables were generated by the Chiang method using the data from Statistics Canada, Health Statistics Division, Vital statistics, 1995 to 1997, 1996 Census (special tabulations); and Statistics Canada, Demography Division, adjusted 1996 Census population calculated for census subdivisions. These health regions are located in the Yukon Territory, Nunavut, and some of the northern regions of Quebec, Ontario, Manitoba and Saskatchewan (Table 4). Aboriginal 
peoples comprised about $20 \%$ of the population in at least nine of these health regions. Two regions, Region of Nunavik and Nunavut- have predominantly Inuit populations. In the remaining seven regions, the Aboriginal populations are predominantly non-Inuit. Hence, we have computed the unweighted average of expectancy of life at birth based on the seven regions. The unweighted average expectancy of life at birth in 1996 was 71.3 years for males and 77.1 years for females. The estimated values of life expectancy at birth by gender for the year 1998 were lower by 3 years over the unweighted average life expectancy at birth levels.

Such a difference between these two estimates of $e_{0}$ is expected, since the unweighted average life expectancy at birth indicates the mortality level of aboriginal and non-aboriginal population which should be higher than that for the Registered Indian population. In addition, these average estimates of $\mathrm{e}_{0}$ lie within the $95 \%$ confidence limits of life expectancy at birth for males and females computed by the Chiang method for the years, 1996-2000 (Appendix Tables 5.1 and 5.2). The confidence limits for the period 1996-2000 were estimated (64.53 and 72.03) for males; and (71.04 and 77.98) for females. Hence, the estimates of life expectancy at birth developed by the Chiang method seem to be satisfactory for understanding the level of health status of the Registered Indian population in Canada. The historical trend of increasing life expectancy at birth over the period 1975-1998 appears to be useful for projecting the future mortality trends among Registered Indians in Canada.

Notwithstanding the above conclusion, the estimates of life expectancy at birth for the Registered Indian population are subject to some limitations. These limitations are determined mostly by the quality of adjustment of deaths and population by age groups. These life tables are, however, the most comprehensive assessment of mortality levels among Registered Indians in Canada.

\section{Analysis of Results}

We compared the life expectation at birth for Registered Indians for males and females at the Canada level with those for the total Canadian population (Table $5)$.

The life expectancies at birth for the Registered Indian population for males and females in 1998 are comparable to those for the Canadian population prior to 1976. During the period 1960-62, the life expectancies for the total Canadian males and females were 68.4 and 74.3 years (Nagnur, 1986). For both, Registered Indians and the total Canadian population, the estimated life 
Ravi B. P. Verma, Margaret Michalowski and R. Pierre Gauvin

expectancy at birth for females is higher than that for males. This pattern is true for all the years. Although gender differences are declining, this decline is relatively more regular and consistent for the total Canadian population than for the Registered Indian population. For the latter, the gender difference was 6.7 years in 1978, declining to 6.2 years in 1998. For the former, the gender difference declined faster, from 7.4 years in 1976 to 5.8 years in 1996.

\section{Table 4}

Health Regions with Low Male and Female Life Expectancy at Birth, by Aboriginal Share of Population, 1996

\begin{tabular}{lcc}
\hline More than 20\% Aboriginal & Males & Females \\
\hline \hline Health Labrador Corporation, Nfld & 69.9 & 77.9 \\
Région des Terres-Cries-de-la-Baie-James, Que. & 70.0 & 76.7 \\
Northwestern Public health Unit, Ont. & 70.3 & 77.8 \\
Norman, Man. & 71.7 & 77.5 \\
Burntwood/Churchill, Man. & 70.4 & 75.6 \\
Northern Health Service Branch (K) Service Area, Sask. & 70.6 & 76.1 \\
Northwestern Regional Health Authority, Alta. & 76.2 & 78.2 \\
Unweighted Average e based on 7 health regions & 71.3 & 77.1 \\
& & \\
Nunavut & 67.8 & 71.2 \\
Région du Nunavik, Que. & 68.8 & 71.5 \\
\hline Less than 20\% Aboriginal & & \\
\hline \hline Timiskaming Public Health Unit, Ont. & 72.8 & 78.7 \\
Peace River Regional Health Authority, Alta. & 69.7 & 78.5 \\
Northern Lights Regional Health Authority, Alta. & 71.4 & 78.0 \\
\hline
\end{tabular}

From Jason Gilmore, 1999. Life Expectancy, Health Reports (Statistics Canada), Vol. II. No. 3, Winter. 
Abridged Life Tables for Registered Indians in Canada,

1976-1980 to 1996-200

Table 5

Comparison of Life Expectancy at Birth by Gender, Registered Indians and Total Canadian Population, Selected Years

\begin{tabular}{cccccc}
\hline & \multicolumn{2}{c}{ Registered Indians } & & \multicolumn{2}{c}{ Canadian Population } \\
\cline { 1 - 3 } Year & Males & Females & Year & Males & Females \\
\hline \hline $\mathbf{1 9 7 8}$ & 59.99 & 66.61 & $\mathbf{1 9 7 6}$ & 70.5 & 77.9 \\
$\mathbf{1 9 8 3}$ & 62.54 & 69.41 & $\mathbf{1 9 8 1}$ & 72.0 & 79.2 \\
$\mathbf{1 9 8 8}$ & 66.42 & 72.49 & $\mathbf{1 9 8 6}$ & 73.3 & 80.0 \\
$\mathbf{1 9 9 3}$ & 67.72 & 73.91 & $\mathbf{1 9 9 1}$ & 74.6 & 81.0 \\
$\mathbf{1 9 9 8}$ & 68.28 & 74.49 & $\mathbf{1 9 9 6}$ & 75.4 & 81.2 \\
\hline
\end{tabular}

In Table 6, we examined the significance of the gender differences in life expectancy by age groups at the Canada level for the period 1996-2000. Let us assume that the estimated life expectancy is a sample mean future lifetime. We used the normal distribution to compare life expectancies for males and females. For each age, the life expectancy and the standard errors are recorded in columns 3 and 5 . The difference for the expectancies is given in column 6 . The ratio of the difference to the corresponding standard error is recorded as the critical ratio in Column 8. It is seen that the critical ratio for each age in Column 8 far exceeds the critical value of $Z .99=2.33$ corresponding to alpha $=.01$ level of significance. This means that according to the 1998 mortality experience among Registered Indians in Canada, a female of any age has a greater life expectancy than a male of the same age.

The excess of male mortality over female for the Registered Indians and the total Canadian population is consistent with the well-known phenomenon in developed countries. A number of hypotheses regarding the gender differentials in survival ratios have been put forward as possible explanations (Nault, 1997, Andreev, 2000, and Trovato and Lalu, 2001). These hypotheses are based mainly on analysis of cause-specific mortality, social and behavioural differences, risk factors (smoking, drinking, etc) prevailing in male and female populations, inherent biological and genetic differences. 
Ravi B. P. Verma, Margaret Michalowski and R. Pierre Gauvin

Table 6

Life Expectancy and the Standard Error for Females and Males, Registered Indians of Canada: 1996-2000

\begin{tabular}{|c|c|c|c|c|c|c|c|}
\hline \multirow{2}{*}{$\begin{array}{c}\text { Age } \\
\text { Interval } \\
\text { (years) } \\
\left(x_{i}, x_{i+1}\right) \\
\end{array}$} & \multicolumn{2}{|c|}{ Females } & \multicolumn{2}{|c|}{ Males } & \multicolumn{2}{|c|}{$\begin{array}{c}\text { Difference } \\
\hat{\mathrm{e}}_{i}(\mathrm{~F})-\hat{e}_{i}(\mathrm{M})\end{array}$} & \multirow{2}{*}{$\begin{array}{c}\text { Critical Ratio } \\
\hat{e}_{i}(\mathrm{~F})-\hat{e}{ }_{i}(\mathrm{M}) \\
\text { S.E.(diff) } \\
(6) /(7)\end{array}$} \\
\hline & $\hat{\mathrm{e}}_{i}$ & $100 S_{\text {ề }}$ & $\hat{\mathrm{e}}_{i}$ & $100 S_{\text {êi }}$ & $(2)-(4)$ & S.E.(diff) & \\
\hline (1) & (2) & (3) & (4) & (5) & (6) & $(7)$ & (8) \\
\hline $0-1$ & $74.49-$ & 1.760 & 68.28 & 1.915 & 6.21 & 2.601 & 238.7 \\
\hline $1-5$ & 74.17 & 1.625 & 67.94 & 1.811 & 6.23 & 2.433 & 256.0 \\
\hline $5-10$ & 70.54 & 1.546 & 64.32 & 1.749 & 6.22 & 2.335 & 266.6 \\
\hline $10-15$ & 66.69 & 1.517 & 59.47 & 1.726 & 6.22 & 2.297 & 270.6 \\
\hline $15-20$ & 60.83 & 1.489 & 54.66 & 1.699 & 6.17 & 2.259 & 273.2 \\
\hline $20-25$ & 56.20 & 1.423 & 50.24 & 1.625 & 5.97 & 2.160 & 276.2 \\
\hline $25-30$ & 51.53 & 1.366 & 46.11 & 1.513 & 5.41 & 2.038 & 265.6 \\
\hline $30-35$ & 46.82 & 1.319 & 41.80 & 1.428 & 5.02 & 1.944 & 258.3 \\
\hline $35-40$ & 42.25 & 1.254 & 37.46 & 1.349 & 4.78 & 1.842 & 259.6 \\
\hline $40-45$ & 37.70 & 1.190 & 33.16 & 1.272 & 4.54 & 1.742 & 260.8 \\
\hline $45-50$ & 33.23 & 1.121 & 28.87 & 1.202 & 4.36 & 1.644 & 265.4 \\
\hline $50-55$ & 28.88 & 1.043 & 24.70 & 1.129 & 4.18 & 1.537 & 272.2 \\
\hline $55-60$ & 24.69 & 0.953 & 20.81 & 1.044 & 3.88 & 1.413 & 274.6 \\
\hline $60-65$ & 20.63 & 0.855 & 17.19 & 0.951 & 3.44 & 1.279 & 269.2 \\
\hline $65-69$ & 16.96 & 0.719 & 13.90 & 0.847 & 3.06 & 1.111 & 275.2 \\
\hline $70-74$ & 13.06 & 0.605 & 10.83 & 0.734 & 2.23 & 0.951 & 234.3 \\
\hline $75-79$ & 9.40 & 0.472 & 8.02 & 0.604 & 1.38 & 0.767 & 179.5 \\
\hline $80-84$ & 5.93 & 0.303 & 5.33 & 0.422 & 0.60 & 0.519 & 115.8 \\
\hline $85+$ & 2.35 & 0 & 2.35 & 0 & 0 & 0 & - \\
\hline
\end{tabular}


An examination of past trends in mortality shows that gains in life expectancy at birth for Registered Indians has increased substantially over the past twenty years and the gap in the life expectancies between the Registered Indian and total Canadian population has narrowed. In 1978, the difference in expectancies of life at birth between the Registered Indian and Canadian total population for males and females was about 10 years. By the year 1998, this difference had narrowed down to 7 years. The gain in life expectancy at birth for Registered Indian males has been estimated at 8.4 years over the period, 1978-1998. A similar improvement has been observed for Registered Indian females, where a gain of 8.0 years in life expectancy has been estimated for the same period. In contrast, the gain in life expectancy at birth for the total Canadian males and females over the last twenty years (1976 to 1996) was much smaller, 4.9 years for males and 3.3 years for females.

The pace of improvement in mortality has changed. Between 1988 and 1993, the gain in life expectancy was 1.3 years for Registered Indian males and 1.5 years for Registered Indian females. However, this was reduced to about half over the period 1993-1998. A similar trend in the reduction of improvement in mortality has been noticed for all Canadian males and females. Between the years, 1986 and 1991, life expectancy at birth for all Canadian males and females increased by one year, but increased only by 0.8 years for males and 0.2 years for females in the following five-year period (Table 5).

Table 7 shows the results of life expectancy at birth for the Registered Indian population for the two broad regions for the years 1978 to 1998.

We have also conducted the analyses with respect to regional differences in life expectancy by age for males and females for the period, 1996-2000 (Table 8). For each age group, the difference in life expectancy is statistically highly significant. Based on the mortality experience among Registered Indians, an Indian Registered male or female of any age residing in the Eastern region has a higher life expectancy than an Indian Registered male or female living in the Western region.

For the total Canadian population, it has been observed that the $\mathrm{e}_{0}$ is generally higher in the western provinces than in the eastern provinces (George, et al. 2001). However, Trovato and Lalu, (2001) observed that the geographic variations in life expectancy have been following a converging trend. The regional variations in $\mathrm{e}_{0}$ for the Registered Indian population are opposite to those of the Canadian population. In the Eastern region, the Registered Indians are expected to live longer than those in the Western region. It is also observed that the $\mathrm{e}_{0}$ for Registered Indian females residing in the Eastern region is 
Ravi B. P. Verma, Margaret Michalowski and R. Pierre Gauvin

converging to the $\mathrm{e}_{0}$ for total Canadian females. These findings are consistent with those by Gilmore (1999:18), who observed that "life expectancy at birth is considerably lower in remote northern health regions than in the rest of Canada. The population of many of these regions includes a significant proportion of Aboriginal people." This could be due to the higher prevalence of mortality due to major chronic diseases among a large proportion of Aboriginal people. Also, in these regions, mortality due to major chronic diseases is higher among women than among men. The higher rates of mortality could also result from the contribution of circulatory disease, cancer and respiratory disease in health regions with a large proportion of Aboriginal people. In 1997, the rate of smoking among adults in the Aboriginal population was double the rate for Canada as a whole. (Federal Provincial and Territorial Advisory Committee on Population Health, 1999). The findings of a study by Statistics Canada (2002) on Health of the Off-reserve Aboriginal population indicated that "Aboriginal people who live off-reserve in cities and towns are generally in poorer health than the non-Aboriginal population". The study found that inequalities in health persisted between Aboriginal people who lived off-reserve and other Canadians after socio-economic and health behaviour factors were taken into account. "In $2000 / 01,79 \%$ of the off-reserve Aboriginal population living in the provinces reported seeing a general practioner at least once in the year before the survey, the same level as the provincial non-Aboriginal population. However, in the territories the off-reserve Aboriginal population was much less likely to have had contact with a doctor (59\%) than the non-Aboriginal population living there $(76 \%)$, and much more likely to have contacted a nurse (49\% compared with

Table 7

Life Expectancy at Birth for the Registered Indian Population for Two Regions (Eastern and Western) for the Years, 1978 to 1998

\begin{tabular}{ccccc}
\hline & \multicolumn{2}{c}{ East Region } & \multicolumn{2}{c}{ West Region } \\
\cline { 2 - 5 } Year & Males & Females & Males & Females \\
\hline \hline $\mathbf{1 9 7 8}$ & 62.12 & 69.43 & 57.79 & 63.87 \\
$\mathbf{1 9 8 3}$ & 64.11 & 71.02 & 60.75 & 67.31 \\
$\mathbf{1 9 8 8}$ & 67.73 & 73.57 & 64.70 & 70.76 \\
$\mathbf{1 9 9 3}$ & 68.98 & 74.87 & 66.01 & 72.42 \\
$\mathbf{1 9 9 8}$ & 69.44 & 75.57 & 66.74 & 72.96 \\
\hline
\end{tabular}


Abridged Life Tables for Registered Indians in Canada, 1976-1980 to 1996-2000

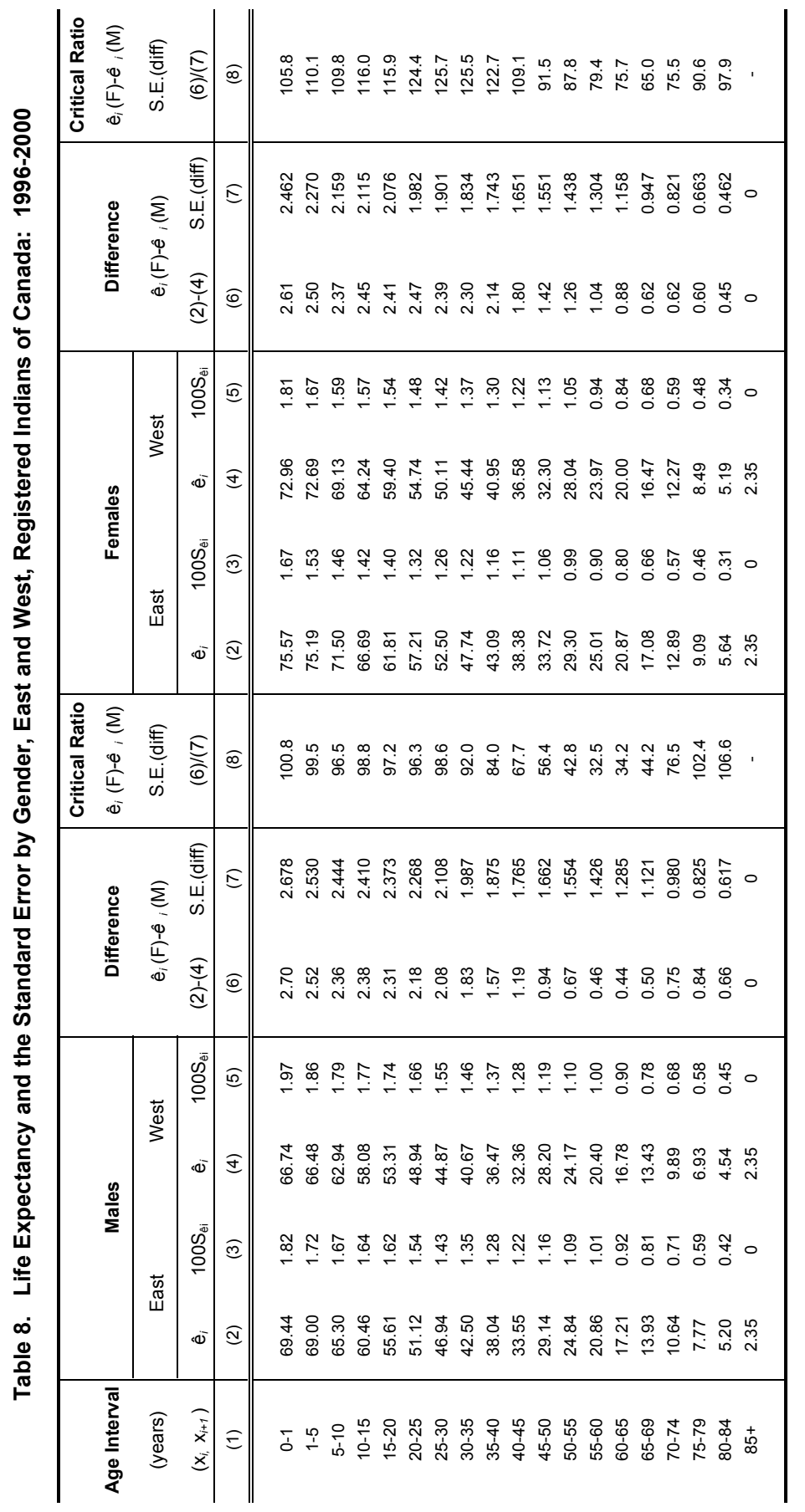


Table 9

Life Expectancy at Birth by Gender for Registered Indians in Canada, Indigenous People in Australia, Maori Population in New Zealand, and American Indian and Alaska Native Population of the United States, for Selected years

\begin{tabular}{ccccc}
\hline Gender & $\begin{array}{c}\text { Canada } \\
\mathbf{1 9 9 6 -} \\
\mathbf{2 0 0 0}\end{array}$ & $\begin{array}{c}\text { Australia* } \\
\mathbf{1 9 9 7 - 1 9 9 9}\end{array}$ & $\begin{array}{c}\text { New Zealand** } \\
\mathbf{1 9 9 5 - 1 9 9 7}\end{array}$ & $\begin{array}{c}\text { United States* } \\
\text { 1996-1998 }\end{array}$ \\
\hline \hline $\begin{array}{c}\text { Males } \\
\text { Female } \\
\mathbf{s}\end{array}$ & 68.3 & 55.6 & 67.2 & 67.0 \\
\hline
\end{tabular}

Sources: * Australian Bureau of Statistics, 2001, Deaths, N. 3302.0, pages 25 and 101.

** Statistics New Zealand. 1998. New Zealand Life Tables, 1995-97 Highlights.

$22 \%$ ). In 2001/02, $20 \%$ of off-reserve Aboriginal people reported an unmet health care need, significantly higher than $13 \%$ for the non-Aboriginal population. This pattern prevailed across all areas examined (Statistics Canada, The Daily, August 27, 2002)". One could make similar analysis of Aboriginal populations living on-reserve using the data form the 2001 Post-censal Aboriginal Peoples Survey.

When comparing with other countries' aboriginal populations, life expectancy at birth for Registered Indians in Canada seems to be similar to that of the Maori population in New Zealand, and the American Indian population and Alaska Native population in the United States (Table 9). The estimates for the Indigenous population in Australia are much lower. The Australian Bureau of Statistics has produced two sets of experimental Indigenous life tables. One set was based on the number of registered deaths which were not adjusted for undercoverage. Like Canada, there is undercoverage of Indigenous deaths to some degree in all states and territories. To compensate for undercoverage, another set was produced after inflating the number of registered deaths in the state or territory by the respective adjustment factor. These adjusted estimates 
of life expectancy at birth for Australia are presented in Table 9. Based on the unadjusted deaths, the observed life expectancy values for the Indigenous population in Australia for the period 1997-1999 were 62.5 years for males and 63.2 years for females. In Canada, the observed life expectancies at birth for Registered Indians, based on the unadjusted deaths and population for the period 1996-2000, were 72.2 years for males, and 77.8 years for females.

\section{Conclusions}

Based on the analyses presented in this paper, there seems to be a substantial level of improvement in mortality rates for Registered Indians in Canada over the period 1975-2000. However, life expectancy at birth for this population is still much lower than that for the total Canadian population. For both the Registered Indian population and the total Canadian population, life expectancy at birth for females is higher than that for males. The gender differences in $\mathrm{e}_{0}$, although narrowing, are relatively higher for the Registered Indian population. Life expectancy at birth for the Registered Indian population living in the Eastern region is higher than for those who live in the Western region. The pattern of regional variation for this population seems to be the reverse of the regional variation for the total Canadian population. However, the $\mathrm{e}_{0}$ for Registered Indian females living in the Eastern region is converging faster to that of all Canadian females.

\section{Acknowledgements:}

The authors appreciate the methodological contribution in developing earlier version of these estimates from Mr. Réjean Lachapelle, Director of Demography Division, Statistics Canada, and Prof. Frank Trovato, University of Alberta; Dr. M. V. George, Demography Division, and Dr. Bali Ram, Housing, Family and Social Statistics Division of Statistics Canada for reviewing this paper, and Dr. Gustave Goldmann, Statistics Canada for discussing this paper at the PAA meeting, 2003. We also thank Julie Dussault for providing technical assistance; and Ian Kisbee for editorial assistance. The authors thank the anonymous reviewers who provided very useful suggestions. 
Ravi B. P. Verma, Margaret Michalowski and R. Pierre Gauvin

\section{End Notes:}

1. A large body of knowledge has been documented which reveals the lower socio-economic conditions of Aboriginal peoples and Registered Indians living in Canada compared to the Canadian population. It reveals show that Registered Indians have lower income levels, higher rates of unemployment, lower success rates within the educational system, and higher fertility and mortality rates. Further reading on these indicators can be found in Health Reports: How Healthy are Canadians? (Statistics Canada, 2000, Catalogue No. 82-003-XPB), Comparison of Social Conditions, 1991 and 1996 (Indian and Northern Affairs Canada, 2000), Understanding Aboriginal Definitions: Implications for Counts and SocioEconomic Characteristics (Andy Siggner, Hull, Vermaeten, Guimond, Jantzen, 2001) etc.

\section{References:}

Australian Bureau of Statistics. 2001. Deaths, N. 3302.0. Canberra.

Brass, W. 1968. "On the Scale of Mortality," in William Brass et al. The Demography of Tropical Africa. Princeton, New Jersey: Princeton University Press, pp. 69-110.

Chiang. C. L. 1984. The Life Table and Its Applications. Malabar, Florida: Robert E. Krieger Publishing Company.

Federal, Provincial and Territorial Advisory Committee on Population Health. 1999. Toward a Healthy Future: Second Report on the Health of Canadians (Catalogue H39-468). Ottawa.

Gilmore, Jason. 1999. Life Expectancy. Health Reports (Statistics Canada), Catalogue 82-003. Vol. II. No. 3. Winter 1999.

Indian Affairs and Northern Development, 2000. Comparison of Social Conditions, 1991 and 1996. See at www.aincinac.gc.ca/pr/sts/hac/socl_e.html.

Loh, S. 1990. Population Projections of Registered Indians, 1986-2011. Report prepared by Population Projections Section, Demography Division, Statistics Canada for Indian and Northern Affairs Canada (INAC). 
George, M.V., Shirley Loh, Ravi B. P. Verma and Edward Shin. 2001. Population Projections for Canada, Provinces and Territories, 20002026. Ottawa: Statistics Canada. Catalogue No. 91-520.

Nagnur, D. 1986. Longevity and Historical Life Tables, 1921-1981 (Abridged), Canada and Provinces. Statistics Canada, Catalogue No. 89-506.

Nault, F., J. Chen, M.V. George and M. J. Norris. 1993. Population Projections of Registered Indians, 1991-2016. Report prepared by the Population Projections Section, Demography Division, Statistics Canada for Indian and Northern Affairs Canada (INAC).

Nault, F., J. Chen and M.J. Norris. 1992. Demographic Time Series Data on Births, Deaths, and Population for Registered Indian Population, Canada, 1973-1990. Report prepared by the Population Projections Section, Demography Division, Statistics Canada for Indian and Northern Affairs Canada (INAC).

Statistics New Zealand. 1998. New Zealand Life Tables, 1995-97 Highlights. Wellington

Norris, M.J., D. Kerr and F. Nault. 1995. Projections of the Population with Aboriginal Identity in Canada, 1991-2016. Report prepared by the Population Projections Section, Demography Division, Statistics Canada for the Royal Commission on Aboriginal Peoples.

Perreault, J., Paquette, L. and M.V. George. 1985. Population Projections of Registered Indians, 1982-1996. Report prepared by the Population Projections Section, Demography Division, Statistics Canada for Indian and Northern Affairs Canada (INAC).

Piché, V. and M.V. George. 1973. "Estimates of Vital Rates for the Canadian Indians, 1960-1970,” Demography 10(3): 367-382.

Saskatchewan Health. 2001. The Epidemiology of Infant Mortality in Saskatchewan, 1982-1996. Saskatoon, Government of Saskatchewan. May.

Siggner, Andy, Jerry Hull, Annette Vermaeten, Eric Guimond and Lorna Janten. 2001. Understanding Aboriginal Definitions: Implications for Counts and Socio-Economic Characteristics. Draft. Ottawa: Indian Affairs and Northern Development. Government of Canada. 
Ravi B. P. Verma, Margaret Michalowski and R. Pierre Gauvin

Statistics Canada. 2000. A Note on the Projections of the Non-registered Indian and Non Indian Populations Living on Reserve, 1998-2008. Prepared by the Population Projections Section, Demography Division, Statistics Canada for the Corporate Information Management Directorate of the Department of Indian Affairs and Northern Development.

Statistics Canada. 2000. Health Reports: How Healthy are Canadians? Catalogue No. 82-003-XPB.

Statistics Canada. 2002. The Health of the Off-reserve Aboriginal Population. Catalogue 82-003-SIE (Free). Also available on Statistics Canada's Web Site (www.statcan.ca).

Statistics Canada. 2002. "Health of the Off-reserve Aboriginal population," The Daily Tuesday, August 27.

Statistics Canada. 2002. Description of Population Projections of Registered Indians for Canada and Regions, 2002-2021. Prepared by the Development and Demographic Methods Section, Demography Division, Statistics Canada for the Corporate Information Management Directorate of the Department of Indian Affairs and Northern Development.

Trovato, Frank and N. Lalu. 2001. "Differentials in Life Expectancy: Regional Variations, 1971-1991," Canadian Studies in Population 28(1): 89110 .

Vital Statistics. 2001. Trends in Mortality and possible causes for Registered Indians. See at www.vs.gov.bc.ca/stats/features/indian/exec.html. Victoria: Government of British Columbia.

Verma, Ravi B. P., Shirley Loh, Edward Ng, R. Pierre Gauvin and Mary Jane Norris. 1999. Evaluation and Adjustment of Demographic Data for Registered Indians in Canada, 1973 to 1996. Presented at the annual meetings of the International Statistical Institute, Finland.

Verma, Ravi B. P., Annette Vermaeten and R. Pierre Gauvin. 2001. Mortality Trends of Registered Indians in Canada, 1972-2000. Published in the proceedings of meetings of the Federation of Canadian Demographers, Ottawa, Ontario, December. 
Ravi B. P. Verma, Margaret Michalowski and R. Pierre Gauvin

Appendix Table 1. Abridged Life Table for Registered Indians, Total Canada, 1976-1980

\begin{tabular}{|c|c|c|c|c|c|c|c|c|c|}
\hline \multirow{2}{*}{$\begin{array}{c}\text { Male } \\
\text { Age interval } \\
\text { (in years) } \\
x \text { to } x+1\end{array}$} & \multirow{2}{*}{$\begin{array}{c}\text { Death } \\
\text { Rate } \\
\text { Mi }\end{array}$} & \multirow{2}{*}{$\begin{array}{c}\text { Fraction } \\
\text { of last age } \\
\text { interval } \\
\text { ai }\end{array}$} & \multirow{2}{*}{$\begin{array}{c}\text { Probability } \\
\text { of dying } \\
\text { in interval } \\
\text { qi }\end{array}$} & \multirow{2}{*}{$\begin{array}{l}\text { No of living } \\
\text { at age } \\
\text { interval } \\
\text { of life } \\
\text { li }\end{array}$} & \multirow{2}{*}{$\begin{array}{c}\text { Number of } \\
\text { Yrs Lived } \\
\text { in interval } \\
\mathrm{Li}\end{array}$} & \multirow{2}{*}{$\begin{array}{l}\text { Total No. of } \\
\text { Yrs Lived } \\
\text { beyond } \\
\text { age } x_{i} \\
T i\end{array}$} & \multirow{2}{*}{$\begin{array}{c}\text { Expectation } \\
\text { of life } \\
\text { at age } x_{i} \\
\text { ei }\end{array}$} & \multicolumn{2}{|c|}{ 95\% Confidence Limits } \\
\hline & & & & & & & & $\begin{array}{c}\text { Lower } \\
\text { Limit }\end{array}$ & $\begin{array}{l}\text { Upper } \\
\text { Limit }\end{array}$ \\
\hline $0-1$ & 0.0339 & 0.15 & 0.0329 & 100000 & 97201 & 5998708 & 59.99 & 55.36 & 64.61 \\
\hline $1-5$ & 0.0024 & 0.39 & 0.0097 & 96706 & 384537 & 5901507 & 61.02 & 56.80 & 65.25 \\
\hline $5-10$ & 0.0012 & 0.47 & 0.0058 & 95768 & 477367 & 5516970 & 57.61 & 53.50 & 61.71 \\
\hline $10-15$ & 0.0012 & 0.55 & 0.0058 & 95212 & 474812 & 5039603 & 52.93 & 48.89 & 56.97 \\
\hline $15-20$ & 0.0050 & 0.56 & 0.0248 & 94658 & 468127 & 4564791 & 48.22 & 44.24 & 52.21 \\
\hline $20-25$ & 0.0073 & 0.50 & 0.0357 & 92311 & 453329 & 4096664 & 44.38 & 40.57 & 48.18 \\
\hline $25-30$ & 0.0070 & 0.51 & 0.0342 & 89020 & 437637 & 3643335 & 40.93 & 37.37 & 44.49 \\
\hline $30-35$ & 0.0072 & 0.53 & 0.0356 & 85974 & 422683 & 3205698 & 37.29 & 33.94 & 40.63 \\
\hline $35-40$ & 0.0090 & 0.53 & 0.0443 & 82916 & 405951 & 2783015 & 33.56 & 30.42 & 36.71 \\
\hline $40-45$ & 0.0097 & 0.53 & 0.0476 & 79244 & 387357 & 2377064 & 30.00 & 27.07 & 32.93 \\
\hline $45-50$ & 0.0121 & 0.54 & 0.0588 & 75472 & 367155 & 1989706 & 26.36 & 23.63 & 29.09 \\
\hline $50-55$ & 0.0148 & 0.52 & 0.0717 & 71035 & 342953 & 1622551 & 22.84 & 20.31 & 25.37 \\
\hline $55-60$ & 0.0213 & 0.53 & 0.1012 & 65943 & 314030 & 1279597 & 19.40 & 17.07 & 21.74 \\
\hline $60-65$ & 0.0263 & 0.52 & 0.1238 & 59269 & 278735 & 965567 & 16.29 & 14.18 & 18.41 \\
\hline $65-69$ & 0.0352 & 0.52 & 0.1623 & 51932 & 239436 & 686833 & 13.23 & 11.33 & 15.12 \\
\hline $70-74$ & 0.0537 & 0.51 & 0.2373 & 43505 & 192235 & 447397 & 10.28 & 8.61 & 11.96 \\
\hline $75-79$ & 0.0800 & 0.50 & 0.3332 & 33182 & 138268 & 255162 & 7.69 & 6.28 & 9.10 \\
\hline $80-84$ & 0.1028 & 0.48 & 0.4055 & 22125 & 87299 & 116895 & 5.28 & 4.29 & 6.28 \\
\hline $85+$ & 0.1885 & 0.45 & 1.0000 & 13154 & 29596 & 29596 & 2.25 & 2.25 & 2.25 \\
\hline
\end{tabular}

\begin{tabular}{|c|c|c|c|c|c|c|c|c|c|}
\hline \multirow{2}{*}{$\begin{array}{l}\text { Female } \\
\text { Age interval } \\
\text { (in years) } \\
x \text { to } x+1\end{array}$} & \multirow{2}{*}{$\begin{array}{c}\text { Death } \\
\text { Rate } \\
\text { Mi }\end{array}$} & \multirow{2}{*}{$\begin{array}{l}\text { Fraction } \\
\text { of last age } \\
\text { interval } \\
\text { ai }\end{array}$} & \multirow{2}{*}{$\begin{array}{c}\text { Probability } \\
\text { of dying } \\
\text { in interval } \\
\text { qi }\end{array}$} & \multirow{2}{*}{$\begin{array}{l}\text { No of living } \\
\text { at age } \\
\text { interval } \\
\text { of life } \\
\text { li }\end{array}$} & \multirow{2}{*}{$\begin{array}{c}\text { Number of } \\
\text { Yrs Lived } \\
\text { in interval } \\
\mathrm{Li}\end{array}$} & \multirow{2}{*}{$\begin{array}{l}\text { Total No. of } \\
\text { Yrs Lived } \\
\text { beyond } \\
\text { age } x_{i} \\
T i\end{array}$} & \multirow{2}{*}{$\begin{array}{c}\text { Expectation } \\
\text { of life } \\
\text { at age } \mathrm{x}_{\mathrm{i}} \\
\text { ei }\end{array}$} & \multicolumn{2}{|c|}{ 95\% Confidence Limits } \\
\hline & & & & & & & & $\begin{array}{c}\text { Lower } \\
\text { Limit }\end{array}$ & $\begin{array}{c}\text { Upper } \\
\text { Limit }\end{array}$ \\
\hline $0-1$ & 0.0292 & 0.15 & 0.0285 & 100000 & 97581 & 6661055 & 66.61 & 62.32 & 70.90 \\
\hline $1-5$ & 0.0017 & 0.39 & 0.0069 & 97154 & 386969 & 6563475 & 67.56 & 63.78 & 71.34 \\
\hline $5-10$ & 0.0007 & 0.47 & 0.0035 & 96479 & 481499 & 6176505 & 64.02 & 60.38 & 67.66 \\
\hline $10-15$ & 0.0007 & 0.55 & 0.0033 & 96141 & 479980 & 5695006 & 59.24 & 55.66 & 62.81 \\
\hline $15-20$ & 0.0022 & 0.56 & 0.0109 & 95819 & 476803 & 5215026 & 54.43 & 50.90 & 57.96 \\
\hline $20-25$ & 0.0029 & 0.50 & 0.0146 & 94777 & 470421 & 4738223 & 49.99 & 46.60 & 53.39 \\
\hline $25-30$ & 0.0033 & 0.51 & 0.0162 & 93391 & 463252 & 4267803 & 45.70 & 42.46 & 48.94 \\
\hline $30-35$ & 0.0040 & 0.53 & 0.0200 & 91879 & 455075 & 3804551 & 41.41 & 38.32 & 44.49 \\
\hline $35-40$ & 0.0059 & 0.53 & 0.0292 & 90040 & 444030 & 3349476 & 37.20 & 34.27 & 40.13 \\
\hline $40-45$ & 0.0069 & 0.53 & 0.0341 & 87414 & 430072 & 2905446 & 33.24 & 30.50 & 35.97 \\
\hline $45-50$ & 0.0090 & 0.54 & 0.0442 & 84436 & 413605 & 2475374 & 29.32 & 26.77 & 31.86 \\
\hline $50-55$ & 0.0105 & 0.52 & 0.0512 & 80708 & 393613 & 2061769 & 25.55 & 23.21 & 27.88 \\
\hline $55-60$ & 0.0139 & 0.53 & 0.0673 & 76572 & 370753 & 1668156 & 21.79 & 19.65 & 23.92 \\
\hline $60-65$ & 0.0195 & 0.52 & 0.0932 & 71420 & 341129 & 1297403 & 18.17 & 16.24 & 20.09 \\
\hline $65-69$ & 0.0266 & 0.52 & 0.1249 & 64765 & 304412 & 956274 & 14.77 & 13.07 & 16.46 \\
\hline $70-74$ & 0.0398 & 0.51 & 0.1813 & 56676 & 258200 & 651862 & 11.50 & 10.04 & 12.96 \\
\hline $75-79$ & 0.0607 & 0.50 & 0.2635 & 46399 & 201423 & 393663 & 8.48 & 7.31 & 9.66 \\
\hline $80-84$ & 0.0811 & 0.48 & 0.3349 & 34171 & 141102 & 192239 & 5.63 & 4.86 & 6.39 \\
\hline $85+$ & 0.0938 & 0.45 & 1.0000 & 22728 & 51138 & 51138 & 2.25 & 2.25 & 2.25 \\
\hline
\end{tabular}

Source: Development \& Demographic Methods Section, Demography Division, Statistics Canada, 2003. 
Abridged Life Tables for Registered Indians in Canada, 1976-1980 to 1996-2000

Appendix Table 2. Abridged Life Table for Registered Indians, Total Canada, 1981-1985

\begin{tabular}{|c|c|c|c|c|c|c|c|c|c|}
\hline \multirow{2}{*}{$\begin{array}{l}\text { Male } \\
\text { Age interval } \\
\text { (in years) } \\
\quad x \text { to } x+1\end{array}$} & \multirow{2}{*}{$\begin{array}{c}\text { Death } \\
\text { Rate } \\
\text { Mi }\end{array}$} & \multirow{2}{*}{$\begin{array}{c}\text { Fraction } \\
\text { of last age } \\
\text { interval } \\
\text { ai }\end{array}$} & \multirow{2}{*}{$\begin{array}{c}\text { Probability } \\
\text { of dying } \\
\text { in interval } \\
\text { qi }\end{array}$} & \multirow{2}{*}{$\begin{array}{l}\text { No of living } \\
\text { at age } \\
\text { interval } \\
\text { of life } \\
\text { li }\end{array}$} & \multirow{2}{*}{$\begin{array}{c}\text { Number of } \\
\text { Yrs Lived } \\
\text { in interval } \\
\mathrm{Li}\end{array}$} & \multirow{2}{*}{$\begin{array}{l}\text { Total No. of } \\
\text { Yrs Lived } \\
\text { beyond } \\
\text { age } x_{i} \\
T i\end{array}$} & \multirow{2}{*}{$\begin{array}{c}\text { Expectation } \\
\text { of life } \\
\text { at age } x_{i} \\
\text { ei }\end{array}$} & \multicolumn{2}{|c|}{ 95\% Confidence Limits } \\
\hline & & & & & & & & $\begin{array}{c}\text { Lower } \\
\text { Limit }\end{array}$ & $\begin{array}{l}\text { Upper } \\
\text { Limit }\end{array}$ \\
\hline $0-1$ & 0.0239 & 0.09 & 0.0234 & 100000 & 97873 & 6254255 & 62.54 & 58.30 & 66.78 \\
\hline $1-5$ & 0.0015 & 0.41 & 0.0061 & 97663 & 389242 & 6156382 & 63.04 & 59.15 & 66.92 \\
\hline $5-10$ & 0.0006 & 0.44 & 0.0032 & 97066 & 484455 & 5767141 & 59.41 & 55.62 & 63.21 \\
\hline $10-15$ & 0.0008 & 0.54 & 0.0040 & 96754 & 482879 & 5282685 & 54.60 & 50.85 & 58.35 \\
\hline $15-20$ & 0.0040 & 0.59 & 0.0198 & 96367 & 477926 & 4799806 & 49.81 & 46.10 & 53.51 \\
\hline $20-25$ & 0.0060 & 0.49 & 0.0296 & 94460 & 465179 & 4321880 & 45.75 & 42.23 & 49.28 \\
\hline $25-30$ & 0.0057 & 0.51 & 0.0279 & 91667 & 452062 & 3856701 & 42.07 & 38.79 & 45.35 \\
\hline $30-35$ & 0.0057 & 0.52 & 0.0280 & 89106 & 439532 & 3404639 & 38.21 & 35.15 & 41.27 \\
\hline $35-40$ & 0.0060 & 0.53 & 0.0294 & 86607 & 427051 & 2965107 & 34.24 & 31.36 & 37.11 \\
\hline $40-45$ & 0.0083 & 0.54 & 0.0407 & 84061 & 412434 & 2538056 & 30.19 & 27.48 & 32.90 \\
\hline $45-50$ & 0.0101 & 0.53 & 0.0492 & 80639 & 393866 & 2125623 & 26.36 & 23.83 & 28.89 \\
\hline $50-55$ & 0.0147 & 0.53 & 0.0709 & 76669 & 370580 & 1731757 & 22.59 & 20.24 & 24.94 \\
\hline $55-60$ & 0.0192 & 0.52 & 0.0919 & 71237 & 340471 & 1361177 & 19.11 & 16.95 & 21.26 \\
\hline $60-65$ & 0.0273 & 0.52 & 0.1282 & 64690 & 303547 & 1020706 & 15.78 & 13.82 & 17.74 \\
\hline $65-69$ & 0.0362 & 0.51 & 0.1664 & 56397 & 258995 & 717159 & 12.72 & 10.97 & 14.46 \\
\hline $70-74$ & 0.0566 & 0.52 & 0.2492 & 47013 & 206950 & 458164 & 9.75 & 8.21 & 11.28 \\
\hline $75-79$ & 0.0908 & 0.51 & 0.3715 & 35299 & 144366 & 251213 & 7.12 & 5.80 & 8.44 \\
\hline $80-84$ & 0.1414 & 0.50 & 0.5225 & 22185 & 81950 & 106848 & 4.82 & 3.81 & 5.82 \\
\hline $85+$ & 0.2382 & 0.47 & 1.0000 & 10595 & 24897 & 24897 & 2.35 & 2.35 & 2.35 \\
\hline
\end{tabular}

\begin{tabular}{|c|c|c|c|c|c|c|c|c|c|}
\hline \multirow{2}{*}{$\begin{array}{l}\text { Female } \\
\text { Age interval } \\
\text { (in years) } \\
x \text { to } x+1\end{array}$} & \multirow{2}{*}{$\begin{array}{c}\text { Death } \\
\text { Rate } \\
\text { Mi }\end{array}$} & \multirow{2}{*}{$\begin{array}{l}\text { Fraction } \\
\text { of last age } \\
\text { interval } \\
\text { ai }\end{array}$} & \multirow{2}{*}{$\begin{array}{c}\text { Probability } \\
\text { of dying } \\
\text { in interval } \\
\text { qi }\end{array}$} & \multirow{2}{*}{$\begin{array}{l}\text { No of living } \\
\text { at age } \\
\text { interval } \\
\text { of life } \\
\text { li }\end{array}$} & \multirow{2}{*}{$\begin{array}{c}\text { Number of } \\
\text { Yrs Lived } \\
\text { in interval } \\
\mathrm{Li}\end{array}$} & \multirow{2}{*}{$\begin{array}{l}\text { Total No. of } \\
\text { Yrs Lived } \\
\text { beyond } \\
\text { age } x_{i} \\
T i\end{array}$} & \multirow{2}{*}{$\begin{array}{c}\text { Expectation } \\
\text { of life } \\
\text { at age } \mathrm{x}_{\mathrm{i}} \\
\text { ei }\end{array}$} & \multicolumn{2}{|c|}{ 95\% Confidence Limits } \\
\hline & & & & & & & & $\begin{array}{c}\text { Lower } \\
\text { Limit }\end{array}$ & $\begin{array}{c}\text { Upper } \\
\text { Limit }\end{array}$ \\
\hline $0-1$ & 0.0209 & 0.15 & 0.0205 & 100000 & 98255 & 6940736 & 69.41 & 65.50 & 73.32 \\
\hline $1-5$ & 0.0013 & 0.41 & 0.0053 & 97947 & 390566 & 6842480 & 69.86 & 66.41 & 73.31 \\
\hline $5-10$ & 0.0004 & 0.44 & 0.0020 & 97429 & 486601 & 6451914 & 66.22 & 62.90 & 69.54 \\
\hline $10-15$ & 0.0006 & 0.54 & 0.0029 & 97235 & 485524 & 5965313 & 61.35 & 58.07 & 64.63 \\
\hline $15-20$ & 0.0014 & 0.59 & 0.0071 & 96953 & 483358 & 5479789 & 56.52 & 53.29 & 59.75 \\
\hline $20-25$ & 0.0020 & 0.49 & 0.0100 & 96267 & 478889 & 4996431 & 51.90 & 48.78 & 55.03 \\
\hline $25-30$ & 0.0027 & 0.51 & 0.0133 & 95308 & 473438 & 4517542 & 47.40 & 44.41 & 50.39 \\
\hline $30-35$ & 0.0032 & 0.52 & 0.0161 & 94042 & 466589 & 4044104 & 43.00 & 40.16 & 45.84 \\
\hline $35-40$ & 0.0036 & 0.53 & 0.0179 & 92533 & 458782 & 3577514 & 38.66 & 35.98 & 41.35 \\
\hline $40-45$ & 0.0055 & 0.54 & 0.0271 & 90881 & 448744 & 3118733 & 34.32 & 31.77 & 36.86 \\
\hline $45-50$ & 0.0057 & 0.53 & 0.0280 & 88420 & 436288 & 2669988 & 30.20 & 27.83 & 32.56 \\
\hline $50-55$ & 0.0093 & 0.53 & 0.0455 & 85947 & 420549 & 2233701 & 25.99 & 23.77 & 28.21 \\
\hline $55-60$ & 0.0147 & 0.52 & 0.0711 & 82039 & 396198 & 1813152 & 22.10 & 20.07 & 24.13 \\
\hline $60-65$ & 0.0164 & 0.52 & 0.0788 & 76207 & 366627 & 1416954 & 18.59 & 16.81 & 20.38 \\
\hline $65-69$ & 0.0233 & 0.53 & 0.1105 & 70203 & 332792 & 1050327 & 14.96 & 13.39 & 16.53 \\
\hline $70-74$ & 0.0368 & 0.53 & 0.1695 & 62448 & 287366 & 717535 & 11.49 & 10.14 & 12.84 \\
\hline $75-79$ & 0.0625 & 0.52 & 0.2719 & 51863 & 225469 & 430169 & 8.29 & 7.20 & 9.39 \\
\hline $80-84$ & 0.0993 & 0.50 & 0.3977 & 37761 & 151256 & 204700 & 5.42 & 4.66 & 6.18 \\
\hline $85+$ & 0.1782 & 0.47 & 1.0000 & 22742 & 53443 & 53443 & 2.35 & 2.35 & 2.35 \\
\hline
\end{tabular}

Source: Development \& Demographic Methods Section, Demography Division, Statistics Canada, 2003. 
Ravi B. P. Verma, Margaret Michalowski and R. Pierre Gauvin

Appendix Table 3. Abridged Life Table for Registered Indians, Total Canada, 1986-1990

\begin{tabular}{|c|c|c|c|c|c|c|c|c|c|}
\hline \multirow{2}{*}{$\begin{array}{c}\text { Male } \\
\text { Age interval } \\
\text { (in years) } \\
x \text { to } x+1\end{array}$} & \multirow{2}{*}{$\begin{array}{c}\text { Death } \\
\text { Rate } \\
\text { Mi }\end{array}$} & \multirow{2}{*}{$\begin{array}{c}\text { Fraction } \\
\text { of last age } \\
\text { interval } \\
\text { ai }\end{array}$} & \multirow{2}{*}{$\begin{array}{c}\text { Probability } \\
\text { of dying } \\
\text { in interval } \\
\text { qi }\end{array}$} & \multirow{2}{*}{$\begin{array}{l}\text { No of living } \\
\text { at age } \\
\text { interval } \\
\text { of life } \\
\text { li }\end{array}$} & \multirow{2}{*}{$\begin{array}{c}\text { Number of } \\
\text { Yrs Lived } \\
\text { in interval } \\
\mathrm{Li}\end{array}$} & \multirow{2}{*}{$\begin{array}{l}\text { Total No. of } \\
\text { Yrs Lived } \\
\text { beyond } \\
\text { age } x_{i} \\
T i\end{array}$} & \multirow{2}{*}{$\begin{array}{c}\text { Expectation } \\
\text { of life } \\
\text { at age } x_{i} \\
\text { ei }\end{array}$} & \multicolumn{2}{|c|}{ 95\% Confidence Limits } \\
\hline & & & & & & & & $\begin{array}{c}\text { Lower } \\
\text { Limit }\end{array}$ & $\begin{array}{l}\text { Upper } \\
\text { Limit } \\
\end{array}$ \\
\hline $0-1$ & 0.0121 & 0.09 & 0.0119 & 100000 & 98913 & 6641678 & 66.42 & 62.54 & 70.29 \\
\hline $1-5$ & 0.0011 & 0.41 & 0.0044 & 98805 & 394199 & 6542765 & 66.22 & 62.58 & 69.86 \\
\hline $5-10$ & 0.0004 & 0.44 & 0.0022 & 98372 & 491247 & 6148566 & 62.50 & 58.95 & 66.06 \\
\hline $10-15$ & 0.0007 & 0.54 & 0.0037 & 98153 & 489936 & 5657318 & 57.64 & 54.12 & 61.16 \\
\hline $15-20$ & 0.0030 & 0.59 & 0.0150 & 97792 & 485955 & 5167383 & 52.84 & 49.37 & 56.31 \\
\hline $20-25$ & 0.0042 & 0.49 & 0.0206 & 96325 & 476574 & 4681428 & 48.60 & 45.30 & 51.90 \\
\hline $25-30$ & 0.0038 & 0.51 & 0.0189 & 94344 & 467357 & 4204855 & 44.57 & 41.49 & 47.65 \\
\hline $30-35$ & 0.0041 & 0.52 & 0.0201 & 92564 & 458343 & 3737497 & 40.38 & 37.48 & 43.28 \\
\hline $35-40$ & 0.0045 & 0.53 & 0.0223 & 90699 & 448740 & 3279154 & 36.15 & 33.42 & 38.89 \\
\hline $40-45$ & 0.0060 & 0.54 & 0.0295 & 88676 & 437361 & 2830414 & 31.92 & 29.33 & 34.51 \\
\hline $45-50$ & 0.0083 & 0.53 & 0.0408 & 86059 & 422040 & 2393053 & 27.81 & 25.37 & 30.24 \\
\hline $50-55$ & 0.0114 & 0.53 & 0.0557 & 82546 & 401925 & 1971013 & 23.88 & 21.61 & 26.15 \\
\hline $55-60$ & 0.0167 & 0.52 & 0.0803 & 77949 & 374718 & 1569087 & 20.13 & 18.04 & 22.22 \\
\hline $60-65$ & 0.0250 & 0.52 & 0.1177 & 71688 & 338185 & 1194370 & 16.66 & 14.76 & 18.56 \\
\hline $65-69$ & 0.0319 & 0.51 & 0.1479 & 63248 & 293316 & 856184 & 13.54 & 11.86 & 15.22 \\
\hline $70-74$ & 0.0487 & 0.52 & 0.2179 & 53891 & 241276 & 562868 & 10.44 & 8.98 & 11.91 \\
\hline $75-79$ & 0.0776 & 0.51 & 0.3261 & 42150 & 177073 & 321592 & 7.63 & 6.41 & 8.85 \\
\hline $80-84$ & 0.1216 & 0.50 & 0.4664 & 28404 & 108902 & 144519 & 5.09 & 4.20 & 5.98 \\
\hline $85+$ & 0.2113 & 0.47 & 1.0000 & 15156 & 35618 & 35618 & 2.35 & 2.35 & 2.35 \\
\hline
\end{tabular}

\begin{tabular}{|c|c|c|c|c|c|c|c|c|c|}
\hline \multirow{2}{*}{$\begin{array}{l}\text { Female } \\
\text { Age interval } \\
\text { (in years) } \\
x \text { to } x+1\end{array}$} & \multirow{2}{*}{$\begin{array}{c}\text { Death } \\
\text { Rate } \\
\text { Mi }\end{array}$} & \multirow{2}{*}{$\begin{array}{l}\text { Fraction } \\
\text { of last age } \\
\text { interval } \\
\text { ai }\end{array}$} & \multirow{2}{*}{$\begin{array}{c}\text { Probability } \\
\text { of dying } \\
\text { in interval } \\
\text { qi }\end{array}$} & \multirow{2}{*}{$\begin{array}{l}\text { No of living } \\
\text { at age } \\
\text { interval } \\
\text { of life } \\
\text { li }\end{array}$} & \multirow{2}{*}{$\begin{array}{c}\text { Number of } \\
\text { Yrs Lived } \\
\text { in interval } \\
\mathrm{Li}\end{array}$} & \multirow{2}{*}{$\begin{array}{l}\text { Total No. of } \\
\text { Yrs Lived } \\
\text { beyond } \\
\text { age } x_{i} \\
T i\end{array}$} & \multirow{2}{*}{$\begin{array}{c}\text { Expectation } \\
\text { of life } \\
\text { at age } x_{i} \\
\text { ei }\end{array}$} & \multicolumn{2}{|c|}{ 95\% Confidence Limits } \\
\hline & & & & & & & & $\begin{array}{c}\text { Lower } \\
\text { Limit }\end{array}$ & $\begin{array}{c}\text { Upper } \\
\text { Limit }\end{array}$ \\
\hline $0-1$ & 0.0114 & 0.09 & 0.0113 & 100000 & 98972 & 7248934 & 72.49 & 68.98 & 75.99 \\
\hline $1-5$ & 0.0008 & 0.41 & 0.0033 & 98870 & 394704 & 7149962 & 72.32 & 69.12 & 75.51 \\
\hline $5-10$ & 0.0005 & 0.44 & 0.0024 & 98541 & 492055 & 6755258 & 68.55 & 65.45 & 71.66 \\
\hline $10-15$ & 0.0005 & 0.54 & 0.0026 & 98309 & 490945 & 6263203 & 63.71 & 60.66 & 66.75 \\
\hline $15-20$ & 0.0012 & 0.59 & 0.0060 & 98049 & 489034 & 5772258 & 58.87 & 55.88 & 61.86 \\
\hline $20-25$ & 0.0015 & 0.49 & 0.0073 & 97459 & 485477 & 5283224 & 54.21 & 51.33 & 57.09 \\
\hline $25-30$ & 0.0018 & 0.51 & 0.0089 & 96746 & 481612 & 4797747 & 49.59 & 46.83 & 52.35 \\
\hline $30-35$ & 0.0023 & 0.52 & 0.0115 & 95882 & 476772 & 4316135 & 45.02 & 42.38 & 47.65 \\
\hline $35-40$ & 0.0026 & 0.53 & 0.0132 & 94783 & 470984 & 3839362 & 40.51 & 38.00 & 43.01 \\
\hline $40-45$ & 0.0038 & 0.54 & 0.0189 & 93535 & 463601 & 3368379 & 36.01 & 33.64 & 38.39 \\
\hline $45-50$ & 0.0049 & 0.53 & 0.0241 & 91763 & 453624 & 2904778 & 31.66 & 29.43 & 33.88 \\
\hline $50-55$ & 0.0067 & 0.53 & 0.0328 & 89554 & 440861 & 2451154 & 27.37 & 25.30 & 29.44 \\
\hline $55-60$ & 0.0099 & 0.52 & 0.0484 & 86614 & 423002 & 2010293 & 23.21 & 21.31 & 25.11 \\
\hline $60-65$ & 0.0156 & 0.52 & 0.0750 & 82418 & 397260 & 1587291 & 19.26 & 17.54 & 20.97 \\
\hline $65-69$ & 0.0195 & 0.51 & 0.0930 & 76238 & 363818 & 1190032 & 15.61 & 14.12 & 17.10 \\
\hline $70-74$ & 0.0325 & 0.52 & 0.1506 & 69147 & 320743 & 826214 & 11.95 & 10.68 & 13.22 \\
\hline $75-79$ & 0.0552 & 0.51 & 0.2431 & 58733 & 258687 & 505472 & 8.61 & 7.59 & 9.63 \\
\hline $80-84$ & 0.0911 & 0.50 & 0.3709 & 44456 & 181060 & 246785 & 5.55 & 4.86 & 6.24 \\
\hline $85+$ & 0.1665 & 0.47 & 1.0000 & 27968 & 65725 & 65725 & 2.35 & 2.35 & 2.35 \\
\hline
\end{tabular}

Source: Development \& Demographic Methods Section, Demography Division, Statistics Canada, 2003. 
Abridged Life Tables for Registered Indians in Canada, 1976-1980 to 1996-2000

Appendix Table 4. Abridged Life Table for Registered Indians, Total Canada, 1991-1995

\begin{tabular}{|c|c|c|c|c|c|c|c|c|c|}
\hline \multirow{2}{*}{$\begin{array}{c}\text { Male } \\
\text { Age interval } \\
\text { (in years) } \\
x \text { to } x+1\end{array}$} & \multirow{2}{*}{$\begin{array}{c}\text { Death } \\
\text { Rate } \\
\text { Mi }\end{array}$} & \multirow{2}{*}{$\begin{array}{c}\text { Fraction } \\
\text { of last age } \\
\text { interval } \\
\text { ai }\end{array}$} & \multirow{2}{*}{$\begin{array}{c}\text { Probability } \\
\text { of dying } \\
\text { in interval } \\
\text { qi }\end{array}$} & \multirow{2}{*}{$\begin{array}{l}\text { No of living } \\
\text { at age } \\
\text { interval } \\
\text { of life } \\
\text { li }\end{array}$} & \multirow{2}{*}{$\begin{array}{c}\text { Number of } \\
\text { Yrs Lived } \\
\text { in interval } \\
\mathrm{Li}\end{array}$} & \multirow{2}{*}{$\begin{array}{l}\text { Total No. of } \\
\text { Yrs Lived } \\
\text { beyond } \\
\text { age } x_{i} \\
T i\end{array}$} & \multirow{2}{*}{$\begin{array}{c}\text { Expectation } \\
\text { of life } \\
\text { at age } x_{i} \\
\text { ei }\end{array}$} & \multicolumn{2}{|c|}{ 95\% Confidence Limits } \\
\hline & & & & & & & & $\begin{array}{c}\text { Lower } \\
\text { Limit }\end{array}$ & $\begin{array}{l}\text { Upper } \\
\text { Limit }\end{array}$ \\
\hline $0-1$ & 0.0108 & 0.09 & 0.0107 & 100000 & 99031 & 6772139 & 67.72 & 63.92 & 71.52 \\
\hline $1-5$ & 0.0009 & 0.41 & 0.0035 & 98935 & 394914 & 6673109 & 67.45 & 63.87 & 71.03 \\
\hline $5-10$ & 0.0005 & 0.44 & 0.0024 & 98585 & 492271 & 6278195 & 63.68 & 60.18 & 67.19 \\
\hline $10-15$ & 0.0005 & 0.54 & 0.0026 & 98351 & 491170 & 5785924 & 58.83 & 55.36 & 62.29 \\
\hline $15-20$ & 0.0027 & 0.59 & 0.0135 & 98096 & 487765 & 5294754 & 53.97 & 50.55 & 57.40 \\
\hline $20-25$ & 0.0036 & 0.49 & 0.0178 & 96771 & 479468 & 4806989 & 49.67 & 46.41 & 52.94 \\
\hline $25-30$ & 0.0039 & 0.51 & 0.0195 & 95051 & 470711 & 4327521 & 45.53 & 42.47 & 48.59 \\
\hline $30-35$ & 0.0033 & 0.52 & 0.0166 & 93196 & 462265 & 3856810 & 41.38 & 38.52 & 44.25 \\
\hline $35-40$ & 0.0046 & 0.53 & 0.0228 & 91648 & 453323 & 3394545 & 37.04 & 34.32 & 39.76 \\
\hline $40-45$ & 0.0053 & 0.54 & 0.0263 & 89556 & 442370 & 2941221 & 32.84 & 30.29 & 35.40 \\
\hline $45-50$ & 0.0075 & 0.53 & 0.0367 & 87204 & 428504 & 2498851 & 28.66 & 26.25 & 31.06 \\
\hline $50-55$ & 0.0098 & 0.53 & 0.0478 & 84006 & 410595 & 2070347 & 24.65 & 22.41 & 26.88 \\
\hline $55-60$ & 0.0159 & 0.52 & 0.0765 & 79991 & 385266 & 1659752 & 20.75 & 18.68 & 22.82 \\
\hline $60-65$ & 0.0215 & 0.52 & 0.1023 & 73870 & 351218 & 1274486 & 17.25 & 15.38 & 19.13 \\
\hline $65-69$ & 0.0304 & 0.51 & 0.1415 & 66315 & 308584 & 923268 & 13.92 & 12.26 & 15.59 \\
\hline $70-74$ & 0.0465 & 0.52 & 0.2091 & 56931 & 256077 & 614685 & 10.80 & 9.35 & 12.24 \\
\hline $75-79$ & 0.0704 & 0.51 & 0.3001 & 45024 & 192012 & 358607 & 7.96 & 6.77 & 9.15 \\
\hline $80-84$ & 0.1081 & 0.50 & 0.4254 & 31511 & 124044 & 166596 & 5.29 & 4.45 & 6.12 \\
\hline $85+$ & 0.1864 & 0.47 & 1.0000 & 18107 & 42552 & 42552 & 2.35 & 2.35 & 2.35 \\
\hline
\end{tabular}

\begin{tabular}{|c|c|c|c|c|c|c|c|c|c|}
\hline \multirow{2}{*}{$\begin{array}{l}\text { Female } \\
\text { Age interval } \\
\text { (in years) } \\
x \text { to } x+1\end{array}$} & \multirow{2}{*}{$\begin{array}{c}\text { Death } \\
\text { Rate } \\
\text { Mi }\end{array}$} & \multirow{2}{*}{$\begin{array}{l}\text { Fraction } \\
\text { of last age } \\
\text { interval } \\
\text { ai }\end{array}$} & \multirow{2}{*}{$\begin{array}{c}\text { Probability } \\
\text { of dying } \\
\text { in interval } \\
\text { qi }\end{array}$} & \multirow{2}{*}{$\begin{array}{l}\text { No of living } \\
\text { at age } \\
\text { interval } \\
\text { of life } \\
\text { li }\end{array}$} & \multirow{2}{*}{$\begin{array}{c}\text { Number of } \\
\text { Yrs Lived } \\
\text { in interval } \\
\mathrm{Li}\end{array}$} & \multirow{2}{*}{$\begin{array}{l}\text { Total No. of } \\
\text { Yrs Lived } \\
\text { beyond } \\
\text { age } x_{i} \\
T i\end{array}$} & \multirow{2}{*}{$\begin{array}{c}\text { Expectation } \\
\text { of life } \\
\text { at age } x_{i} \\
\text { ei }\end{array}$} & \multicolumn{2}{|c|}{ 95\% Confidence Limits } \\
\hline & & & & & & & & $\begin{array}{c}\text { Lower } \\
\text { Limit }\end{array}$ & $\begin{array}{c}\text { Upper } \\
\text { Limit }\end{array}$ \\
\hline $0-1$ & 0.0101 & 0.09 & 0.0100 & 100000 & 99086 & 7390660 & 73.91 & 70.49 & 77.32 \\
\hline $1-5$ & 0.0007 & 0.41 & 0.0028 & 98996 & 395329 & 7291574 & 73.66 & 70.53 & 76.78 \\
\hline $5-10$ & 0.0003 & 0.44 & 0.0016 & 98719 & 493148 & 6896245 & 69.86 & 66.82 & 72.90 \\
\hline $10-15$ & 0.0004 & 0.54 & 0.0021 & 98560 & 492333 & 6403096 & 64.97 & 61.97 & 67.96 \\
\hline $15-20$ & 0.0014 & 0.59 & 0.0070 & 98357 & 490373 & 5910763 & 60.09 & 57.15 & 63.04 \\
\hline $20-25$ & 0.0013 & 0.49 & 0.0064 & 97668 & 486751 & 5420390 & 55.50 & 52.69 & 58.31 \\
\hline $25-30$ & 0.0016 & 0.51 & 0.0080 & 97045 & 483312 & 4933639 & 50.84 & 48.14 & 53.54 \\
\hline $30-35$ & 0.0018 & 0.52 & 0.0091 & 96264 & 479228 & 4450328 & 46.23 & 43.65 & 48.81 \\
\hline $35-40$ & 0.0025 & 0.53 & 0.0122 & 95392 & 474216 & 3971100 & 41.63 & 39.17 & 44.09 \\
\hline $40-45$ & 0.0030 & 0.54 & 0.0150 & 94224 & 467871 & 3496884 & 37.11 & 34.78 & 39.44 \\
\hline $45-50$ & 0.0042 & 0.53 & 0.0208 & 92811 & 459526 & 3029013 & 32.64 & 30.44 & 34.84 \\
\hline $50-55$ & 0.0063 & 0.53 & 0.0310 & 90884 & 447796 & 2569488 & 28.27 & 26.22 & 30.33 \\
\hline $55-60$ & 0.0094 & 0.52 & 0.0461 & 88065 & 430573 & 2121691 & 24.09 & 22.21 & 25.98 \\
\hline $60-65$ & 0.0145 & 0.52 & 0.0700 & 84001 & 405901 & 1691119 & 20.13 & 18.45 & 21.82 \\
\hline $65-69$ & 0.0163 & 0.51 & 0.0786 & 78124 & 375575 & 1285218 & 16.45 & 15.01 & 17.89 \\
\hline $70-74$ & 0.0266 & 0.52 & 0.1251 & 71983 & 338309 & 909642 & 12.64 & 11.42 & 13.85 \\
\hline $75-79$ & 0.0458 & 0.51 & 0.2059 & 62980 & 283133 & 571333 & 9.07 & 8.11 & 10.03 \\
\hline $80-84$ & 0.0783 & 0.50 & 0.3273 & 50014 & 209140 & 288199 & 5.76 & 5.13 & 6.39 \\
\hline $85+$ & 0.1531 & 0.47 & 1.0000 & 33642 & 79059 & 79059 & 2.35 & 2.35 & 2.35 \\
\hline
\end{tabular}

Source: Development \& Demographic Methods Section, Demography Division, Statistics Canada, 2003. 
Ravi B. P. Verma, Margaret Michalowski and R. Pierre Gauvin

Appendix Table 5. Abridged Life Table for Registered Indians, Total Canada, 1996-2000

\begin{tabular}{|c|c|c|c|c|c|c|c|c|c|}
\hline \multirow{2}{*}{$\begin{array}{c}\text { Male } \\
\text { Age interval } \\
\text { (in years) } \\
x \text { to } x+1\end{array}$} & \multirow{2}{*}{$\begin{array}{c}\text { Death } \\
\text { Rate } \\
\text { Mi }\end{array}$} & \multirow{2}{*}{$\begin{array}{c}\text { Fraction } \\
\text { of last age } \\
\text { interval } \\
\text { ai }\end{array}$} & \multirow{2}{*}{$\begin{array}{c}\text { Probability } \\
\text { of dying } \\
\text { in interval } \\
\text { qi }\end{array}$} & \multirow{2}{*}{$\begin{array}{l}\text { No of living } \\
\text { at age } \\
\text { interval } \\
\text { of life } \\
\text { li }\end{array}$} & \multirow{2}{*}{$\begin{array}{c}\text { Number of } \\
\text { Yrs Lived } \\
\text { in interval } \\
\mathrm{Li}\end{array}$} & \multirow{2}{*}{$\begin{array}{l}\text { Total No. of } \\
\text { Yrs Lived } \\
\text { beyond } \\
\text { age } x_{i} \\
T i\end{array}$} & \multirow{2}{*}{$\begin{array}{l}\text { Expectation } \\
\text { of life } \\
\text { at age } x_{i} \\
\text { ei }\end{array}$} & \multicolumn{2}{|c|}{ 95\% Confidence Limits } \\
\hline & & & & & & & & $\begin{array}{c}\text { Lower } \\
\text { Limit }\end{array}$ & $\begin{array}{l}\text { Upper } \\
\text { Limit }\end{array}$ \\
\hline $0-1$ & 0.0097 & 0.09 & 0.0096 & 100000 & 99129 & 6827787 & 68.28 & 64.53 & 72.03 \\
\hline $1-5$ & 0.0014 & 0.41 & 0.0057 & 99043 & 394845 & 6728658 & 67.94 & 64.39 & 71.49 \\
\hline $5-10$ & 0.0005 & 0.44 & 0.0025 & 98481 & 491726 & 6333813 & 64.32 & 60.89 & 67.74 \\
\hline $10-15$ & 0.0007 & 0.54 & 0.0033 & 98239 & 490438 & 5842087 & 59.47 & 56.09 & 62.85 \\
\hline $15-20$ & 0.0022 & 0.59 & 0.0110 & 97910 & 487339 & 5351649 & 54.66 & 51.33 & 57.99 \\
\hline $20-25$ & 0.0036 & 0.49 & 0.0181 & 96831 & 479695 & 4864310 & 50.24 & 47.05 & 53.42 \\
\hline $25-30$ & 0.0031 & 0.51 & 0.0154 & 95082 & 471812 & 4384615 & 46.11 & 43.15 & 49.08 \\
\hline $30-35$ & 0.0034 & 0.52 & 0.0167 & 93614 & 464313 & 3912803 & 41.80 & 39.00 & 44.60 \\
\hline $35-40$ & 0.0040 & 0.53 & 0.0196 & 92049 & 455997 & 3448491 & 37.46 & 34.82 & 40.11 \\
\hline $40-45$ & 0.0046 & 0.54 & 0.0227 & 90241 & 446487 & 2992494 & 33.16 & 30.67 & 35.66 \\
\hline $45-50$ & 0.0062 & 0.53 & 0.0307 & 88189 & 434586 & 2546007 & 28.87 & 26.51 & 31.23 \\
\hline $50-55$ & 0.0098 & 0.53 & 0.0481 & 85482 & 417753 & 2111421 & 24.70 & 22.49 & 26.91 \\
\hline $55-60$ & 0.0146 & 0.52 & 0.0704 & 81372 & 393115 & 1693668 & 20.81 & 18.77 & 22.86 \\
\hline $60-65$ & 0.0221 & 0.52 & 0.1049 & 75645 & 359188 & 1300553 & 17.19 & 15.33 & 19.06 \\
\hline $65-69$ & 0.0312 & 0.51 & 0.1451 & 67713 & 314498 & 941365 & 13.90 & 12.24 & 15.56 \\
\hline $70-74$ & 0.0468 & 0.52 & 0.2104 & 57890 & 260224 & 626867 & 10.83 & 9.39 & 12.27 \\
\hline $75-79$ & 0.0695 & 0.51 & 0.2971 & 45712 & 195289 & 366643 & 8.02 & 6.84 & 9.20 \\
\hline $80-84$ & 0.1050 & 0.50 & 0.4159 & 32131 & 127249 & 171355 & 5.33 & 4.51 & 6.16 \\
\hline $85+$ & 0.1770 & 0.47 & 1.0000 & 18768 & 44106 & 44106 & 2.35 & 2.35 & 2.35 \\
\hline
\end{tabular}

\begin{tabular}{|c|c|c|c|c|c|c|c|c|c|}
\hline \multirow{2}{*}{$\begin{array}{l}\text { Female } \\
\text { Age interval } \\
\text { (in years) } \\
x \text { to } x+1\end{array}$} & \multirow{2}{*}{$\begin{array}{c}\text { Death } \\
\text { Rate } \\
\text { Mi }\end{array}$} & \multirow{2}{*}{$\begin{array}{l}\text { Fraction } \\
\text { of last age } \\
\text { interval } \\
\text { ai }\end{array}$} & \multirow{2}{*}{$\begin{array}{c}\text { Probability } \\
\text { of dying } \\
\text { in interval } \\
\text { qi }\end{array}$} & \multirow{2}{*}{$\begin{array}{l}\text { No of living } \\
\text { at age } \\
\text { interval } \\
\text { of life } \\
\text { li }\end{array}$} & \multirow{2}{*}{$\begin{array}{c}\text { Number of } \\
\text { Yrs Lived } \\
\text { in interval } \\
\mathrm{Li}\end{array}$} & \multirow{2}{*}{$\begin{array}{l}\text { Total No. of } \\
\text { Yrs Lived } \\
\text { beyond } \\
\text { age } x_{i} \\
T i\end{array}$} & \multirow{2}{*}{$\begin{array}{c}\text { Expectation } \\
\text { of life } \\
\text { at age } x_{i} \\
\text { ei }\end{array}$} & \multicolumn{2}{|c|}{ 95\% Confidence Limits } \\
\hline & & & & & & & & $\begin{array}{c}\text { Lower } \\
\text { Limit }\end{array}$ & $\begin{array}{c}\text { Upper } \\
\text { Limit }\end{array}$ \\
\hline $0-1$ & 0.0091 & 0.09 & 0.0090 & 100000 & 99177 & 7448670 & 74.49 & 71.04 & 77.94 \\
\hline $1-5$ & 0.0013 & 0.41 & 0.0051 & 99095 & 395183 & 7349493 & 74.17 & 70.98 & 77.35 \\
\hline $5-10$ & 0.0004 & 0.44 & 0.0021 & 98588 & 492351 & 6954310 & 70.54 & 67.51 & 73.57 \\
\hline $10-15$ & 0.0005 & 0.54 & 0.0023 & 98378 & 491365 & 6461959 & 65.69 & 62.71 & 68.66 \\
\hline $15-20$ & 0.0013 & 0.59 & 0.0063 & 98150 & 489473 & 5970594 & 60.83 & 57.91 & 63.75 \\
\hline $20-25$ & 0.0012 & 0.49 & 0.0061 & 97527 & 486131 & 5481121 & 56.20 & 53.41 & 58.99 \\
\hline $25-30$ & 0.0012 & 0.51 & 0.0059 & 96937 & 483285 & 4994990 & 51.53 & 48.85 & 54.21 \\
\hline $30-35$ & 0.0019 & 0.52 & 0.0096 & 96366 & 479613 & 4511704 & 46.82 & 44.23 & 49.40 \\
\hline $35-40$ & 0.0023 & 0.53 & 0.0114 & 95442 & 474644 & 4032091 & 42.25 & 39.79 & 44.71 \\
\hline $40-45$ & 0.0030 & 0.54 & 0.0148 & 94350 & 468531 & 3557447 & 37.70 & 35.37 & 40.04 \\
\hline $45-50$ & 0.0042 & 0.53 & 0.0209 & 92951 & 460196 & 3088916 & 33.23 & 31.03 & 35.43 \\
\hline $50-55$ & 0.0061 & 0.53 & 0.0300 & 91011 & 448640 & 2628720 & 28.88 & 26.84 & 30.93 \\
\hline $55-60$ & 0.0083 & 0.52 & 0.0408 & 88281 & 432762 & 2180080 & 24.69 & 22.83 & 26.56 \\
\hline $60-65$ & 0.0141 & 0.52 & 0.0684 & 84680 & 409495 & 1747318 & 20.63 & 18.96 & 22.31 \\
\hline $65-69$ & 0.0147 & 0.51 & 0.0708 & 78887 & 380741 & 1337823 & 16.96 & 15.55 & 18.37 \\
\hline $70-74$ & 0.0240 & 0.52 & 0.1135 & 73298 & 346515 & 957082 & 13.06 & 11.87 & 14.24 \\
\hline $75-79$ & 0.0403 & 0.51 & 0.1833 & 64976 & 295692 & 610567 & 9.40 & 8.47 & 10.32 \\
\hline $80-84$ & 0.0684 & 0.50 & 0.2920 & 53063 & 226584 & 314875 & 5.93 & 5.34 & 6.53 \\
\hline $85+$ & 0.1407 & 0.47 & 1.0000 & 37571 & 88291 & 88291 & 2.35 & 2.35 & 2.35 \\
\hline
\end{tabular}

Source: Development \& Demographic Methods Section, Demography Division, Statistics Canada, 2003. 
Abridged Life Tables for Registered Indians in Canada, 1976-1980 to 1996-2000

Appendix Table 6. Abridged Life Table for Registered Indians, Eastern Region, Canada, 1976-1980

\begin{tabular}{|c|c|c|c|c|c|c|c|c|c|}
\hline \multirow{2}{*}{$\begin{array}{c}\text { Male } \\
\text { Age interval } \\
\text { (in years) } \\
x \text { to } x+1\end{array}$} & \multirow{2}{*}{$\begin{array}{l}\text { Death } \\
\text { Rate } \\
\text { Mi }\end{array}$} & \multirow{2}{*}{$\begin{array}{c}\text { Fraction } \\
\text { of last age } \\
\text { interval } \\
\text { ai }\end{array}$} & \multirow{2}{*}{$\begin{array}{c}\text { Probability } \\
\text { of dying } \\
\text { in interval } \\
\text { qi }\end{array}$} & \multirow{2}{*}{$\begin{array}{l}\text { No of living } \\
\text { at age } \\
\text { interval } \\
\text { of life } \\
\text { li }\end{array}$} & \multirow{2}{*}{$\begin{array}{c}\text { Number of } \\
\text { Yrs Lived } \\
\text { in interval } \\
\mathrm{Li} \\
\end{array}$} & \multirow{2}{*}{$\begin{array}{l}\text { Total No. of } \\
\text { Yrs Lived } \\
\text { beyond } \\
\text { age } x_{i} \\
T i\end{array}$} & \multirow{2}{*}{$\begin{array}{c}\text { Expectation } \\
\text { of life } \\
\text { at age } x_{i} \\
\text { ei }\end{array}$} & \multicolumn{2}{|c|}{ 95\% Confidence Limits } \\
\hline & & & & & & & & $\begin{array}{c}\text { Lower } \\
\text { Limit }\end{array}$ & $\begin{array}{l}\text { Upper } \\
\text { Limit }\end{array}$ \\
\hline $0-1$ & 0.0274 & 0.15 & 0.0268 & 100000 & 97722 & 6211536 & 62.12 & 57.69 & 66.54 \\
\hline $1-5$ & 0.0020 & 0.39 & 0.0080 & 97320 & 387386 & 6113813 & 62.82 & 58.77 & 66.87 \\
\hline $5-10$ & 0.0011 & 0.47 & 0.0057 & 96544 & 481271 & 5726428 & 59.31 & 55.38 & 63.24 \\
\hline $10-15$ & 0.0009 & 0.55 & 0.0047 & 95998 & 478969 & 5245156 & 54.64 & 50.78 & 58.50 \\
\hline $15-20$ & 0.0044 & 0.56 & 0.0217 & 95544 & 473161 & 4766187 & 49.88 & 46.08 & 53.69 \\
\hline $20-25$ & 0.0055 & 0.5 & 0.0272 & 93471 & 460993 & 4293027 & 45.93 & 42.31 & 49.55 \\
\hline $25-30$ & 0.0063 & 0.51 & 0.0312 & 90926 & 447688 & 3832034 & 42.14 & 38.75 & 45.54 \\
\hline $30-35$ & 0.0059 & 0.53 & 0.0291 & 88093 & 434437 & 3384345 & 38.42 & 35.25 & 41.58 \\
\hline $35-40$ & 0.0075 & 0.53 & 0.0367 & 85528 & 420269 & 2949908 & 34.49 & 31.51 & 37.47 \\
\hline $40-45$ & 0.0081 & 0.53 & 0.0396 & 82391 & 404284 & 2529639 & 30.70 & 27.93 & 33.47 \\
\hline $45-50$ & 0.0099 & 0.54 & 0.0486 & 79127 & 386784 & 2125355 & 26.86 & 24.27 & 29.45 \\
\hline $50-55$ & 0.0143 & 0.52 & 0.0692 & 75279 & 363898 & 1738571 & 23.10 & 20.69 & 25.50 \\
\hline $55-60$ & 0.0191 & 0.53 & 0.0914 & 70072 & 335308 & 1374673 & 19.62 & 17.42 & 21.82 \\
\hline $60-65$ & 0.0264 & 0.52 & 0.1243 & 63667 & 299338 & 1039365 & 16.32 & 14.34 & 18.31 \\
\hline $65-69$ & 0.0300 & 0.52 & 0.1397 & 55751 & 260058 & 740027 & 13.27 & 11.53 & 15.02 \\
\hline $70-74$ & 0.0553 & 0.51 & 0.2437 & 47960 & 211166 & 479969 & 10.01 & 8.47 & 11.55 \\
\hline $75-79$ & 0.0775 & 0.5 & 0.3247 & 36272 & 151914 & 268803 & 7.41 & 6.13 & 8.69 \\
\hline $80-84$ & 0.1391 & 0.48 & 0.5109 & 24493 & 89933 & 116889 & 4.77 & 3.81 & 5.73 \\
\hline $85+$ & 0.1484 & 0.45 & 1.0000 & 11981 & 26956 & 26956 & 2.25 & 2.25 & 2.25 \\
\hline $\begin{array}{c}\text { Female } \\
\text { Age interval }\end{array}$ & Death & $\begin{array}{c}\text { Fraction } \\
\text { of last age }\end{array}$ & $\begin{array}{c}\text { Probability } \\
\text { of dying }\end{array}$ & $\begin{array}{l}\text { No of living } \\
\text { at age } \\
\text { interval }\end{array}$ & $\begin{array}{l}\text { Number of } \\
\text { Yrs Lived }\end{array}$ & $\begin{array}{l}\text { Total No. of } \\
\text { Yrs Lived } \\
\text { beyond }\end{array}$ & $\begin{array}{l}\text { Expectation } \\
\text { of life }\end{array}$ & $95 \%$ Cor & ce Limits \\
\hline $\begin{array}{l}\text { (in years) } \\
x \text { to } x+1\end{array}$ & $\begin{array}{c}\text { Rate } \\
\text { Mi }\end{array}$ & $\begin{array}{c}\text { interval } \\
\text { ai }\end{array}$ & $\begin{array}{c}\text { in interval } \\
\text { qi }\end{array}$ & $\begin{array}{c}\text { of life } \\
\text { li }\end{array}$ & $\begin{array}{c}\text { in interval } \\
\mathrm{Li}\end{array}$ & $\begin{array}{c}\text { age } x_{i} \\
T i\end{array}$ & $\begin{array}{c}\text { at age } x_{i} \\
\text { ei }\end{array}$ & $\begin{array}{c}\text { Lower } \\
\text { Limit }\end{array}$ & $\begin{array}{l}\text { Upper } \\
\text { Limit }\end{array}$ \\
\hline $0-1$ & 0.0248 & 0.15 & 0.0243 & 100000 & 97937 & 6942809 & 69.43 & 65.44 & 73.41 \\
\hline $1-5$ & 0.0014 & 0.39 & 0.0057 & 97573 & 388939 & 6844872 & 70.15 & 66.71 & 73.59 \\
\hline $5-10$ & 0.0005 & 0.47 & 0.0026 & 97019 & 484417 & 6455932 & 66.54 & 63.24 & 69.85 \\
\hline $10-15$ & 0.0007 & 0.55 & 0.0035 & 96764 & 483063 & 5971515 & 61.71 & 58.46 & 64.96 \\
\hline $15-20$ & 0.0015 & 0.56 & 0.0076 & 96428 & 480519 & 5488452 & 56.92 & 53.73 & 60.10 \\
\hline $20-25$ & 0.0019 & 0.5 & 0.0092 & 95691 & 476246 & 5007933 & 52.33 & 49.27 & 55.40 \\
\hline $25-30$ & 0.0020 & 0.51 & 0.0100 & 94808 & 471722 & 4531687 & 47.80 & 44.86 & 50.73 \\
\hline $30-35$ & 0.0026 & 0.53 & 0.0127 & 93862 & 466505 & 4059965 & 43.25 & 40.44 & 46.07 \\
\hline $35-40$ & 0.0037 & 0.53 & 0.0183 & 92668 & 459345 & 3593460 & 38.78 & 36.09 & 41.47 \\
\hline $40-45$ & 0.0055 & 0.53 & 0.0273 & 90968 & 448998 & 3134115 & 34.45 & 31.91 & 37.00 \\
\hline $45-50$ & 0.0063 & 0.54 & 0.0309 & 88482 & 436114 & 2685117 & 30.35 & 27.99 & 32.71 \\
\hline $50-55$ & 0.0084 & 0.52 & 0.0409 & 85744 & 420295 & 2249002 & 26.23 & 24.04 & 28.42 \\
\hline $55-60$ & 0.0125 & 0.53 & 0.0609 & 82233 & 399396 & 1828707 & 22.24 & 20.22 & 24.25 \\
\hline $60-65$ & 0.0185 & 0.52 & 0.0884 & 77224 & 369737 & 1429312 & 18.51 & 16.69 & 20.32 \\
\hline $65-69$ & 0.0224 & 0.52 & 0.1063 & 70397 & 334031 & 1059575 & 15.05 & 13.47 & 16.63 \\
\hline $70-74$ & 0.0401 & 0.51 & 0.1827 & 62916 & 286414 & 725544 & 11.53 & 10.17 & 12.89 \\
\hline $75-79$ & 0.0515 & 0.5 & 0.2282 & 51420 & 227760 & 439130 & 8.54 & 7.48 & 9.60 \\
\hline $80-84$ & 0.0999 & 0.48 & 0.3966 & 39684 & 157496 & 211369 & 5.33 & 4.59 & 6.06 \\
\hline $85+$ & 0.0998 & 0.45 & 1.0000 & 23944 & 53873 & 53873 & 2.25 & 2.25 & 2.25 \\
\hline
\end{tabular}

Note: Eastern Region: Atlantic, Quebec, Ontario and Manitoba

Source: Development \& Demographic Methods Section, Demography Division, Statistics Canada, 2003. 
Ravi B. P. Verma, Margaret Michalowski and R. Pierre Gauvin

\begin{tabular}{|c|c|c|c|c|c|c|c|c|c|}
\hline \multirow{2}{*}{$\begin{array}{c}\text { Age interval } \\
\text { (in years) } \\
x \text { to } x+1\end{array}$} & \multirow{2}{*}{$\begin{array}{c}\text { Death } \\
\text { Rate } \\
\text { Mi }\end{array}$} & \multirow{2}{*}{$\begin{array}{l}\text { Fraction } \\
\text { of last age } \\
\text { interval } \\
\text { ai }\end{array}$} & \multirow{2}{*}{$\begin{array}{c}\text { Probability } \\
\text { of dying } \\
\text { in interval } \\
\text { qi }\end{array}$} & \multirow{2}{*}{$\begin{array}{c}\text { No of living } \\
\text { at age } \\
\text { interval } \\
\text { of life } \\
\text { li }\end{array}$} & \multirow{2}{*}{$\begin{array}{c}\text { Number of } \\
\text { Yrs Lived } \\
\text { in interval } \\
\mathrm{Li}\end{array}$} & \multirow{2}{*}{$\begin{array}{l}\text { Total No. of } \\
\text { Yrs Lived } \\
\text { beyond } \\
\text { age } x_{i} \\
T i\end{array}$} & \multirow{2}{*}{$\begin{array}{c}\text { Expectation } \\
\text { of life } \\
\text { at age } x_{i} \\
\text { ei }\end{array}$} & \multicolumn{2}{|c|}{ 95\% Confidence Limits } \\
\hline & & & & & & & & $\begin{array}{c}\text { Lower } \\
\text { Limit }\end{array}$ & $\begin{array}{l}\text { Upper } \\
\text { Limit }\end{array}$ \\
\hline $0-1$ & 0.0197 & 0.09 & 0.0194 & 100000 & 98235 & 6410917 & 64.11 & 60.06 & 68.16 \\
\hline $1-5$ & 0.0013 & 0.41 & 0.0051 & 98060 & 391069 & 6312682 & 64.38 & 60.65 & 68.10 \\
\hline $5-10$ & 0.0006 & 0.44 & 0.0032 & 97564 & 486939 & 5921613 & 60.69 & 57.06 & 64.33 \\
\hline $10-15$ & 0.0007 & 0.54 & 0.0033 & 97249 & 485507 & 5434674 & 55.88 & 52.30 & 59.47 \\
\hline $15-20$ & 0.0036 & 0.59 & 0.0178 & 96928 & 481101 & 4949167 & 51.06 & 47.52 & 54.60 \\
\hline $20-25$ & 0.0050 & 0.49 & 0.0245 & 95202 & 470051 & 4468066 & 46.93 & 43.57 & 50.29 \\
\hline $25-30$ & 0.0049 & 0.51 & 0.0241 & 92865 & 458854 & 3998015 & 43.05 & 39.93 & 46.18 \\
\hline $30-35$ & 0.0043 & 0.52 & 0.0212 & 90632 & 448537 & 3539161 & 39.05 & 36.14 & 41.96 \\
\hline $35-40$ & 0.0055 & 0.53 & 0.0270 & 88706 & 437902 & 3090625 & 34.84 & 32.09 & 37.60 \\
\hline $40-45$ & 0.0067 & 0.54 & 0.0328 & 86311 & 425036 & 2652722 & 30.73 & 28.15 & 33.32 \\
\hline $45-50$ & 0.0081 & 0.53 & 0.0399 & 83476 & 409550 & 2227687 & 26.69 & 24.26 & 29.11 \\
\hline $50-55$ & 0.0136 & 0.53 & 0.0661 & 80144 & 388274 & 1818137 & 22.69 & 20.41 & 24.96 \\
\hline $55-60$ & 0.0176 & 0.52 & 0.0844 & 74848 & 359074 & 1429863 & 19.10 & 17.01 & 21.20 \\
\hline $60-65$ & 0.0278 & 0.52 & 0.1304 & 68529 & 321191 & 1070789 & 15.63 & 13.70 & 17.55 \\
\hline $65-69$ & 0.0380 & 0.51 & 0.1740 & 59590 & 272547 & 749598 & 12.58 & 10.85 & 14.31 \\
\hline $70-74$ & 0.0592 & 0.52 & 0.2590 & 49221 & 215510 & 477051 & 9.69 & 8.14 & 11.24 \\
\hline $75-79$ & 0.0994 & 0.51 & 0.3997 & 36473 & 146645 & 261541 & 7.17 & 5.81 & 8.54 \\
\hline $80-84$ & 0.1107 & 0.50 & 0.4334 & 21894 & 85745 & 114896 & 5.25 & 4.24 & 6.25 \\
\hline $85+$ & 0.1270 & 0.47 & 1.0000 & 12405 & 29151 & 29151 & 2.35 & 2.35 & 2.35 \\
\hline $\begin{array}{c}\text { Female } \\
\text { Age interval }\end{array}$ & Death & $\begin{array}{l}\text { Fraction } \\
\text { of last age }\end{array}$ & $\begin{array}{l}\text { Probability } \\
\text { of dying }\end{array}$ & $\begin{array}{l}\text { No of living } \\
\text { at age } \\
\text { interval }\end{array}$ & $\begin{array}{l}\text { Number of } \\
\text { Yrs Lived }\end{array}$ & $\begin{array}{l}\text { Total No. of } \\
\text { Yrs Lived } \\
\text { beyond }\end{array}$ & $\begin{array}{l}\text { Expectation } \\
\text { of life }\end{array}$ & $95 \%$ Cor & ce Limits \\
\hline $\begin{array}{c}\text { (in years) } \\
x \text { to } x+1\end{array}$ & $\begin{array}{c}\text { Rate } \\
\mathrm{Mi}\end{array}$ & $\begin{array}{c}\text { interval } \\
\text { ai }\end{array}$ & $\begin{array}{c}\text { in interval } \\
\text { qi }\end{array}$ & $\begin{array}{l}\text { of life } \\
\text { li }\end{array}$ & $\begin{array}{c}\text { in interval } \\
\mathrm{Li}\end{array}$ & $\begin{array}{c}\text { age } x_{i} \\
T i\end{array}$ & $\begin{array}{c}\text { at age } x_{i} \\
\text { ei }\end{array}$ & $\begin{array}{c}\text { Lower } \\
\text { Limit }\end{array}$ & $\begin{array}{l}\text { Upper } \\
\text { Limit }\end{array}$ \\
\hline $0-1$ & 0.0194 & 0.09 & 0.0191 & 100000 & 98261 & 7102023 & 71.02 & 67.36 & 74.68 \\
\hline $1-5$ & 0.0012 & 0.41 & 0.0050 & 98089 & 391210 & 7003762 & 71.40 & 68.24 & 74.57 \\
\hline $5-10$ & 0.0004 & 0.44 & 0.0022 & 97603 & 487427 & 6612552 & 67.75 & 64.73 & 70.77 \\
\hline $10-15$ & 0.0005 & 0.54 & 0.0027 & 97393 & 486370 & 6125125 & 62.89 & 59.92 & 65.86 \\
\hline $15-20$ & 0.0010 & 0.59 & 0.0051 & 97134 & 484649 & 5638755 & 58.05 & 55.14 & 60.96 \\
\hline $20-25$ & 0.0013 & 0.49 & 0.0065 & 96635 & 481567 & 5154106 & 53.34 & 50.52 & 56.15 \\
\hline $25-30$ & 0.0017 & 0.51 & 0.0083 & 96004 & 478070 & 4672539 & 48.67 & 45.96 & 51.38 \\
\hline $30-35$ & 0.0019 & 0.52 & 0.0093 & 95208 & 473908 & 4194469 & 44.06 & 41.45 & 46.66 \\
\hline $35-40$ & 0.0023 & 0.53 & 0.0114 & 94320 & 469064 & 3720560 & 39.45 & 36.95 & 41.94 \\
\hline $40-45$ & 0.0039 & 0.54 & 0.0191 & 93241 & 462100 & 3251496 & 34.87 & 32.48 & 37.26 \\
\hline $45-50$ & 0.0044 & 0.53 & 0.0215 & 91456 & 452651 & 2789396 & 30.50 & 28.25 & 32.75 \\
\hline $50-55$ & 0.0092 & 0.53 & 0.0450 & 89486 & 437965 & 2336745 & 26.11 & 23.98 & 28.25 \\
\hline $55-60$ & 0.0114 & 0.52 & 0.0554 & 85458 & 415930 & 1898780 & 22.22 & 20.28 & 24.16 \\
\hline $60-65$ & 0.0166 & 0.52 & 0.0797 & 80724 & 388174 & 1482851 & 18.37 & 16.61 & 20.13 \\
\hline $65-69$ & 0.0243 & 0.51 & 0.1145 & 74288 & 350604 & 1094677 & 14.74 & 13.17 & 16.30 \\
\hline $70-74$ & 0.0400 & 0.52 & 0.1823 & 65784 & 300137 & 744073 & 11.31 & 9.95 & 12.67 \\
\hline $75-79$ & 0.0725 & 0.51 & 0.3080 & 53791 & 228371 & 443937 & 8.25 & 7.12 & 9.39 \\
\hline $80-84$ & 0.0766 & 0.50 & 0.3215 & 37226 & 156209 & 215565 & 5.79 & 5.06 & 6.52 \\
\hline $85+$ & 0.0957 & 0.47 & 1.0000 & 25258 & 59356 & 59356 & 2.35 & 2.35 & 2.35 \\
\hline
\end{tabular}

Note: Eastern Region: Atlantic, Quebec, Ontario and Manitoba

Source: Development \& Demographic Methods Section, Demography Division, Statistics Canada, 2003. 
Abridged Life Tables for Registered Indians in Canada, 1976-1980 to 1996-2000

Appendix Table 8. Abridged Life Table for Registered Indians, Eastern Region, Canada, 1986-1990

\begin{tabular}{|c|c|c|c|c|c|c|c|c|c|}
\hline $\begin{array}{c}\text { Male } \\
\text { Age interval }\end{array}$ & Death & $\begin{array}{l}\text { Fraction } \\
\text { of last age }\end{array}$ & $\begin{array}{l}\text { Probability } \\
\text { of dying }\end{array}$ & $\begin{array}{l}\text { No of living } \\
\text { at age } \\
\text { interval }\end{array}$ & $\begin{array}{l}\text { Number of } \\
\text { Yrs Lived }\end{array}$ & $\begin{array}{l}\text { Total No. of } \\
\text { Yrs Lived } \\
\text { beyond }\end{array}$ & $\begin{array}{l}\text { Expectation } \\
\text { of life }\end{array}$ & \multicolumn{2}{|c|}{ 95\% Confidence Limits } \\
\hline $\begin{array}{l}\text { (in years) } \\
x \text { to } x+1\end{array}$ & $\begin{array}{c}\text { Rate } \\
\mathrm{Mi}\end{array}$ & $\begin{array}{c}\text { interval } \\
\text { ai }\end{array}$ & $\begin{array}{c}\text { in interval } \\
\text { qi }\end{array}$ & $\begin{array}{c}\text { of life } \\
\text { li }\end{array}$ & $\begin{array}{c}\text { in interval } \\
\mathrm{Li}\end{array}$ & $\begin{array}{c}\text { age } x_{i} \\
T i\end{array}$ & $\begin{array}{c}\text { at age } x_{i} \\
\text { ei }\end{array}$ & $\begin{array}{c}\text { Lower } \\
\text { Limit }\end{array}$ & $\begin{array}{l}\text { Upper } \\
\text { Limit }\end{array}$ \\
\hline $0-1$ & 0.0098 & 0.09 & 0.0097 & 100000 & 99120 & 6773250 & 67.73 & 64.11 & 71.36 \\
\hline $1-5$ & 0.0009 & 0.41 & 0.0036 & 99033 & 395295 & 6674129 & 67.39 & 63.98 & 70.81 \\
\hline $5-10$ & 0.0003 & 0.44 & 0.0016 & 98678 & 492941 & 6278835 & 63.63 & 60.29 & 66.97 \\
\hline $10-15$ & 0.0007 & 0.54 & 0.0033 & 98518 & 491836 & 5785894 & 58.73 & 55.42 & 62.04 \\
\hline $15-20$ & 0.0023 & 0.59 & 0.0112 & 98191 & 488691 & 5294058 & 53.92 & 50.66 & 57.17 \\
\hline $20-25$ & 0.0033 & 0.49 & 0.0165 & 97087 & 481354 & 4805367 & 49.50 & 46.39 & 52.60 \\
\hline $25-30$ & 0.0029 & 0.51 & 0.0143 & 95486 & 474084 & 4324013 & 45.28 & 42.37 & 48.19 \\
\hline $30-35$ & 0.0030 & 0.52 & 0.0151 & 94120 & 467180 & 3849929 & 40.90 & 38.14 & 43.67 \\
\hline $35-40$ & 0.0039 & 0.53 & 0.0194 & 92695 & 459245 & 3382749 & 36.49 & 33.86 & 39.12 \\
\hline $40-45$ & 0.0050 & 0.54 & 0.0247 & 90894 & 449316 & 2923504 & 32.16 & 29.67 & 34.66 \\
\hline $45-50$ & 0.0073 & 0.53 & 0.0357 & 88653 & 435821 & 2474188 & 27.91 & 25.55 & 30.26 \\
\hline $50-55$ & 0.0108 & 0.53 & 0.0529 & 85486 & 416807 & 2038367 & 23.84 & 21.64 & 26.05 \\
\hline $55-60$ & 0.0171 & 0.52 & 0.0823 & 80966 & 388829 & 1621561 & 20.03 & 17.99 & 22.07 \\
\hline $60-65$ & 0.0248 & 0.52 & 0.1170 & 74299 & 350636 & 1232731 & 16.59 & 14.74 & 18.44 \\
\hline $65-69$ & 0.0300 & 0.51 & 0.1395 & 65607 & 305609 & 882095 & 13.45 & 11.81 & 15.08 \\
\hline $70-74$ & 0.0530 & 0.52 & 0.2353 & 56453 & 250389 & 576486 & 10.21 & 8.77 & 11.65 \\
\hline $75-79$ & 0.0799 & 0.51 & 0.3342 & 43171 & 180503 & 326098 & 7.55 & 6.34 & 8.76 \\
\hline $80-84$ & 0.1232 & 0.50 & 0.4710 & 28742 & 109865 & 145595 & 5.07 & 4.18 & 5.95 \\
\hline $85+$ & 0.0981 & 0.47 & 1.0000 & 15204 & 35730 & 35730 & 2.35 & 2.35 & 2.35 \\
\hline $\begin{array}{c}\text { Female } \\
\text { Age interval }\end{array}$ & Death & $\begin{array}{l}\text { Fraction } \\
\text { of last age }\end{array}$ & $\begin{array}{l}\text { Probability } \\
\text { of dying }\end{array}$ & $\begin{array}{l}\text { No of living } \\
\text { at age } \\
\text { interval }\end{array}$ & $\begin{array}{l}\text { Number of } \\
\text { Yrs Lived }\end{array}$ & $\begin{array}{l}\text { Total No. of } \\
\text { Yrs Lived } \\
\text { beyond }\end{array}$ & $\begin{array}{l}\text { Expectation } \\
\text { of life }\end{array}$ & $95 \%$ Cor & ce Limits \\
\hline $\begin{array}{l}\text { (in years) } \\
x \text { to } x+1\end{array}$ & $\begin{array}{c}\text { Rate } \\
\mathrm{Mi}\end{array}$ & $\begin{array}{c}\text { interval } \\
\text { ai }\end{array}$ & $\begin{array}{c}\text { in interval } \\
\text { qi }\end{array}$ & $\begin{array}{c}\text { of life } \\
\text { li }\end{array}$ & $\begin{array}{c}\text { in interval } \\
\mathrm{Li}\end{array}$ & $\begin{array}{c}\text { age } x_{i} \\
\mathrm{Ti}\end{array}$ & $\begin{array}{c}\text { at age } x_{i} \\
\text { ei }\end{array}$ & $\begin{array}{c}\text { Lower } \\
\text { Limit }\end{array}$ & $\begin{array}{l}\text { Upper } \\
\text { Limit }\end{array}$ \\
\hline $0-1$ & 0.0088 & 0.09 & 0.0087 & 100000 & 99210 & 7356674 & 73.57 & 70.34 & 76.79 \\
\hline $1-5$ & 0.0009 & 0.41 & 0.0036 & 99132 & 395691 & 7257464 & 73.21 & 70.26 & 76.16 \\
\hline $5-10$ & 0.0004 & 0.44 & 0.0018 & 98777 & 493401 & 6861773 & 69.47 & 66.63 & 72.31 \\
\hline $10-15$ & 0.0004 & 0.54 & 0.0022 & 98604 & 492530 & 6368372 & 64.59 & 61.80 & 67.38 \\
\hline $15-20$ & 0.0008 & 0.59 & 0.0042 & 98391 & 491117 & 5875843 & 59.72 & 56.98 & 62.46 \\
\hline $20-25$ & 0.0009 & 0.49 & 0.0046 & 97982 & 488769 & 5384725 & 54.96 & 52.31 & 57.61 \\
\hline $25-30$ & 0.0015 & 0.51 & 0.0074 & 97534 & 485914 & 4895956 & 50.20 & 47.63 & 52.76 \\
\hline $30-35$ & 0.0018 & 0.52 & 0.0089 & 96817 & 482025 & 4410043 & 45.55 & 43.10 & 48.00 \\
\hline $35-40$ & 0.0016 & 0.53 & 0.0078 & 95959 & 478033 & 3928017 & 40.93 & 38.60 & 43.27 \\
\hline $40-45$ & 0.0034 & 0.54 & 0.0167 & 95209 & 472394 & 3449985 & 36.24 & 33.98 & 38.49 \\
\hline $45-50$ & 0.0037 & 0.53 & 0.0182 & 93621 & 464099 & 2977591 & 31.80 & 29.69 & 33.91 \\
\hline $50-55$ & 0.0057 & 0.53 & 0.0282 & 91916 & 453493 & 2513492 & 27.35 & 25.36 & 29.33 \\
\hline $55-60$ & 0.0100 & 0.52 & 0.0486 & 89326 & 436203 & 2059998 & 23.06 & 21.22 & 24.90 \\
\hline $60-65$ & 0.0157 & 0.52 & 0.0757 & 84982 & 409477 & 1623796 & 19.11 & 17.45 & 20.76 \\
\hline $65-69$ & 0.0170 & 0.51 & 0.0815 & 78552 & 377081 & 1214319 & 15.46 & 14.04 & 16.88 \\
\hline $70-74$ & 0.0345 & 0.52 & 0.1594 & 72153 & 333158 & 837238 & 11.60 & 10.36 & 12.84 \\
\hline $75-79$ & 0.0609 & 0.51 & 0.2648 & 60651 & 263908 & 504080 & 8.31 & 7.30 & 9.32 \\
\hline $80-84$ & 0.1015 & 0.50 & 0.4049 & 44591 & 177815 & 240172 & 5.39 & 4.69 & 6.08 \\
\hline $85+$ & 0.0881 & 0.47 & 1.0000 & 26535 & 62356 & 62356 & 2.35 & 2.35 & 2.35 \\
\hline
\end{tabular}

Note: Eastern Region: Atlantic, Quebec, Ontario and Manitoba

Source: Development \& Demographic Methods Section, Demography Division, Statistics Canada, 2003. 
Ravi B. P. Verma, Margaret Michalowski and R. Pierre Gauvin

Appendix Table 9. Abridged Life Table for Registered Indians, Eastern Region, Canada, 1991-1995

\begin{tabular}{|c|c|c|c|c|c|c|c|c|c|}
\hline $\begin{array}{c}\text { Male } \\
\text { Age interval }\end{array}$ & Death & $\begin{array}{c}\text { Fraction } \\
\text { of last age }\end{array}$ & $\begin{array}{c}\text { Probability } \\
\text { of dying }\end{array}$ & $\begin{array}{c}\text { No of living } \\
\text { at age } \\
\text { interval }\end{array}$ & $\begin{array}{l}\text { Number of } \\
\text { Yrs Lived }\end{array}$ & $\begin{array}{l}\text { Total No. of } \\
\text { Yrs Lived } \\
\text { beyond }\end{array}$ & $\begin{array}{l}\text { Expectation } \\
\text { of life }\end{array}$ & \multicolumn{2}{|c|}{ 95\% Confidence Limits } \\
\hline $\begin{array}{l}\text { (in years) } \\
x \text { to } x+1\end{array}$ & $\begin{array}{c}\text { Rate } \\
\text { Mi }\end{array}$ & $\begin{array}{c}\text { interval } \\
\text { ai }\end{array}$ & $\begin{array}{c}\text { in interval } \\
\text { qi }\end{array}$ & $\begin{array}{c}\text { of life } \\
\text { li }\end{array}$ & $\begin{array}{c}\text { in interval } \\
\mathrm{Li}\end{array}$ & $\begin{array}{c}\text { age } x_{i} \\
\mathrm{Ti}\end{array}$ & $\begin{array}{c}\text { at age } x_{i} \\
\text { ei }\end{array}$ & $\begin{array}{l}\text { Lower } \\
\text { Limit }\end{array}$ & $\begin{array}{l}\text { Upper } \\
\text { Limit }\end{array}$ \\
\hline $0-1$ & 0.0082 & 0.09 & 0.0081 & 100000 & 99259 & 6897621 & 68.98 & 65.36 & 72.60 \\
\hline $1-5$ & 0.0009 & 0.41 & 0.0034 & 99186 & 395944 & 6798362 & 68.54 & 65.11 & 71.98 \\
\hline $5-10$ & 0.0004 & 0.44 & 0.0022 & 98847 & 493633 & 6402418 & 64.77 & 61.41 & 68.13 \\
\hline $10-15$ & 0.0005 & 0.54 & 0.0026 & 98632 & 492567 & 5908785 & 59.91 & 56.59 & 63.22 \\
\hline $15-20$ & 0.0024 & 0.59 & 0.0118 & 98374 & 489491 & 5416218 & 55.06 & 51.78 & 58.33 \\
\hline $20-25$ & 0.0030 & 0.49 & 0.0151 & 97213 & 482330 & 4926727 & 50.68 & 47.57 & 53.79 \\
\hline $25-30$ & 0.0033 & 0.51 & 0.0163 & 95748 & 474929 & 4444397 & 46.42 & 43.50 & 49.34 \\
\hline $30-35$ & 0.0026 & 0.52 & 0.0130 & 94192 & 468015 & 3969468 & 42.14 & 39.40 & 44.88 \\
\hline $35-40$ & 0.0038 & 0.53 & 0.0190 & 92965 & 460670 & 3501453 & 37.66 & 35.05 & 40.28 \\
\hline $40-45$ & 0.0045 & 0.54 & 0.0221 & 91197 & 451347 & 3040783 & 33.34 & 30.88 & 35.81 \\
\hline $45-50$ & 0.0065 & 0.53 & 0.0319 & 89180 & 439217 & 2589436 & 29.04 & 26.71 & 31.37 \\
\hline $50-55$ & 0.0092 & 0.53 & 0.0452 & 86336 & 422503 & 2150219 & 24.91 & 22.73 & 27.08 \\
\hline $55-60$ & 0.0150 & 0.52 & 0.0723 & 82431 & 397856 & 1727716 & 20.96 & 18.95 & 22.97 \\
\hline $60-65$ & 0.0205 & 0.52 & 0.0975 & 76473 & 364463 & 1329861 & 17.39 & 15.58 & 19.20 \\
\hline $65-69$ & 0.0275 & 0.51 & 0.1289 & 69014 & 323269 & 965397 & 13.99 & 12.39 & 15.59 \\
\hline $70-74$ & 0.0466 & 0.52 & 0.2094 & 60116 & 270370 & 642128 & 10.68 & 9.28 & 12.08 \\
\hline $75-79$ & 0.0763 & 0.51 & 0.3214 & 47528 & 200222 & 371758 & 7.82 & 6.65 & 9.00 \\
\hline $80-84$ & 0.1060 & 0.50 & 0.4189 & 32255 & 127493 & 171537 & 5.32 & 4.49 & 6.14 \\
\hline $85+$ & 0.0955 & 0.47 & 1.0000 & 18742 & 44044 & 44044 & 2.35 & 2.35 & 2.35 \\
\hline $\begin{array}{l}\text { Female } \\
\text { Age interval }\end{array}$ & Death & $\begin{array}{l}\text { Fraction } \\
\text { of last age }\end{array}$ & $\begin{array}{l}\text { Probability } \\
\text { of dying }\end{array}$ & $\begin{array}{c}\text { No of living } \\
\text { at age } \\
\text { interval }\end{array}$ & $\begin{array}{l}\text { Number of } \\
\text { Yrs Lived }\end{array}$ & $\begin{array}{l}\text { Total No. of } \\
\text { Yrs Lived } \\
\text { beyond }\end{array}$ & $\begin{array}{l}\text { Expectation } \\
\text { of life }\end{array}$ & \multicolumn{2}{|c|}{ 95\% Confidence Limits } \\
\hline $\begin{array}{c}\text { (in years) } \\
x \text { to } x+1\end{array}$ & $\begin{array}{c}\text { Rate } \\
\mathrm{Mi}\end{array}$ & $\begin{array}{c}\text { interval } \\
\text { ai }\end{array}$ & $\begin{array}{c}\text { in interval } \\
\text { qi }\end{array}$ & $\begin{array}{l}\text { of life } \\
\mathrm{li}\end{array}$ & $\begin{array}{c}\text { in interval } \\
\mathrm{Li}\end{array}$ & $\begin{array}{c}\text { age } x_{i} \\
\mathrm{Ti}\end{array}$ & $\begin{array}{c}\text { at age } x_{i} \\
\text { ei }\end{array}$ & $\begin{array}{c}\text { Lower } \\
\text { Limit }\end{array}$ & $\begin{array}{l}\text { Upper } \\
\text { Limit }\end{array}$ \\
\hline $0-1$ & 0.0085 & 0.09 & 0.0084 & 100000 & 99234 & 7487401 & 74.87 & 71.69 & 78.06 \\
\hline $1-5$ & 0.0007 & 0.41 & 0.0028 & 99159 & 395984 & 7388166 & 74.51 & 71.60 & 77.42 \\
\hline $5-10$ & 0.0003 & 0.44 & 0.0016 & 98883 & 493980 & 6992183 & 70.71 & 67.89 & 73.53 \\
\hline $10-15$ & 0.0003 & 0.54 & 0.0017 & 98728 & 493254 & 6498202 & 65.82 & 63.05 & 68.59 \\
\hline $15-20$ & 0.0014 & 0.59 & 0.0068 & 98560 & 491437 & 6004949 & 60.93 & 58.20 & 63.66 \\
\hline $20-25$ & 0.0009 & 0.49 & 0.0043 & 97895 & 488410 & 5513511 & 56.32 & 53.74 & 58.90 \\
\hline $25-30$ & 0.0011 & 0.51 & 0.0056 & 97477 & 486049 & 5025102 & 51.55 & 49.06 & 54.04 \\
\hline $30-35$ & 0.0012 & 0.52 & 0.0062 & 96931 & 483222 & 4539052 & 46.83 & 44.43 & 49.22 \\
\hline $35-40$ & 0.0018 & 0.53 & 0.0089 & 96333 & 479663 & 4055830 & 42.10 & 39.79 & 44.41 \\
\hline $40-45$ & 0.0024 & 0.54 & 0.0117 & 95480 & 474822 & 3576168 & 37.45 & 35.25 & 39.66 \\
\hline $45-50$ & 0.0033 & 0.53 & 0.0165 & 94359 & 468146 & 3101345 & 32.87 & 30.77 & 34.96 \\
\hline $50-55$ & 0.0056 & 0.53 & 0.0277 & 92806 & 457986 & 2633200 & 28.37 & 26.40 & 30.34 \\
\hline $55-60$ & 0.0092 & 0.52 & 0.0452 & 90234 & 441373 & 2175213 & 24.11 & 22.29 & 25.92 \\
\hline $60-65$ & 0.0139 & 0.52 & 0.0670 & 86152 & 416902 & 1733840 & 20.13 & 18.52 & 21.73 \\
\hline $65-69$ & 0.0136 & 0.51 & 0.0658 & 80378 & 388929 & 1316938 & 16.38 & 15.03 & 17.74 \\
\hline $70-74$ & 0.0251 & 0.52 & 0.1185 & 75088 & 354082 & 928009 & 12.36 & 11.19 & 13.53 \\
\hline $75-79$ & 0.0530 & 0.51 & 0.2344 & 66188 & 292930 & 573928 & 8.67 & 7.72 & 9.63 \\
\hline $80-84$ & 0.0914 & 0.50 & 0.3721 & 50673 & 206227 & 280998 & 5.55 & 4.90 & 6.19 \\
\hline $85+$ & 0.1007 & 0.47 & 1.0000 & 31817 & 74771 & 74771 & 2.35 & 2.35 & 2.35 \\
\hline
\end{tabular}

Note: Eastern Region: Atlantic, Quebec, Ontario and Manitoba

Source: Development \& Demographic Methods Section, Demography Division, Statistics Canada, 2003. 
Abridged Life Tables for Registered Indians in Canada, 1976-1980 to 1996-2000

Appendix Table 10. Abridged Life Table for Registered Indians, Eastern Region, Canada, 1996-2000

\begin{tabular}{|c|c|c|c|c|c|c|c|c|c|}
\hline \multirow{2}{*}{$\begin{array}{c}\text { Male } \\
\text { Age interval } \\
\text { (in years) } \\
x \text { to } x+1\end{array}$} & \multirow{2}{*}{$\begin{array}{c}\text { Death } \\
\text { Rate } \\
\text { Mi }\end{array}$} & \multirow{2}{*}{$\begin{array}{c}\text { Fraction } \\
\text { of last age } \\
\text { interval } \\
\text { ai }\end{array}$} & \multirow{2}{*}{$\begin{array}{c}\text { Probability } \\
\text { of dying } \\
\text { in interval } \\
\text { qi }\end{array}$} & \multirow{2}{*}{$\begin{array}{c}\text { No of living } \\
\text { at age } \\
\text { interval } \\
\text { of life } \\
\text { li }\end{array}$} & \multirow{2}{*}{$\begin{array}{c}\text { Number of } \\
\text { Yrs Lived } \\
\text { in interval } \\
\mathrm{Li} \\
\end{array}$} & \multirow{2}{*}{$\begin{array}{c}\text { Total No. of } \\
\text { Yrs Lived } \\
\text { beyond } \\
\text { age } x_{i} \\
T i\end{array}$} & \multirow{2}{*}{$\begin{array}{c}\text { Expectation } \\
\text { of life } \\
\text { at age } x_{i} \\
\text { ei }\end{array}$} & \multicolumn{2}{|c|}{ 95\% Confidence Limits } \\
\hline & & & & & & & & $\begin{array}{c}\text { Lower } \\
\text { Limit }\end{array}$ & $\begin{array}{c}\text { Upper } \\
\text { Limit }\end{array}$ \\
\hline $0-1$ & 0.0082 & 0.09 & 0.0081 & 100000 & 99263 & 6943564 & 69.44 & 65.88 & 72.99 \\
\hline $1-5$ & 0.0011 & 0.41 & 0.0044 & 99190 & 395735 & 6844301 & 69.00 & 65.63 & 72.37 \\
\hline 5-10 & 0.0005 & 0.44 & 0.0026 & 98756 & 493061 & 6448566 & 65.30 & 62.03 & 68.56 \\
\hline $10-15$ & 0.0005 & 0.54 & 0.0026 & 98500 & 491912 & 5955504 & 60.46 & 57.25 & 63.67 \\
\hline $15-20$ & 0.0019 & 0.59 & 0.0096 & 98245 & 489291 & 5463592 & 55.61 & 52.45 & 58.78 \\
\hline $20-25$ & 0.0033 & 0.49 & 0.0166 & 97302 & 482388 & 4974301 & 51.12 & 48.10 & 54.15 \\
\hline $25-30$ & 0.0025 & 0.51 & 0.0124 & 95686 & 475526 & 4491914 & 46.94 & 44.15 & 49.74 \\
\hline $30-35$ & 0.0027 & 0.52 & 0.0133 & 94501 & 469480 & 4016388 & 42.50 & 39.85 & 45.15 \\
\hline $35-40$ & 0.0029 & 0.53 & 0.0143 & 93241 & 463080 & 3546908 & 38.04 & 35.53 & 40.55 \\
\hline $40-45$ & 0.0038 & 0.54 & 0.0186 & 91911 & 455615 & 3083828 & 33.55 & 31.16 & 35.94 \\
\hline $45-50$ & 0.0052 & 0.53 & 0.0258 & 90197 & 445514 & 2628213 & 29.14 & 26.87 & 31.41 \\
\hline $50-55$ & 0.0090 & 0.53 & 0.0439 & 87868 & 430284 & 2182700 & 24.84 & 22.70 & 26.98 \\
\hline $55-60$ & 0.0143 & 0.52 & 0.0692 & 84014 & 406128 & 1752415 & 20.86 & 18.87 & 22.84 \\
\hline $60-65$ & 0.0221 & 0.52 & 0.1050 & 78205 & 371318 & 1346287 & 17.21 & 15.41 & 19.02 \\
\hline $65-69$ & 0.0279 & 0.51 & 0.1307 & 69994 & 327563 & 974970 & 13.93 & 12.34 & 15.51 \\
\hline $70-74$ & 0.0466 & 0.52 & 0.2097 & 60848 & 273620 & 647407 & 10.64 & 9.26 & 12.02 \\
\hline $75-79$ & 0.0750 & 0.51 & 0.3169 & 48089 & 203114 & 373787 & 7.77 & 6.62 & 8.92 \\
\hline $80-84$ & 0.1142 & 0.50 & 0.4443 & 32851 & 127770 & 170673 & 5.20 & 4.37 & 6.02 \\
\hline $85+$ & 0.0975 & 0.47 & 1.0000 & 18257 & 42903 & 42903 & 2.35 & 2.35 & 2.35 \\
\hline $\begin{array}{c}\text { Female } \\
\text { Age interval }\end{array}$ & Death & $\begin{array}{l}\text { Fraction } \\
\text { of last age }\end{array}$ & $\begin{array}{l}\text { Probability } \\
\text { of dying }\end{array}$ & $\begin{array}{l}\text { No of living } \\
\text { at age } \\
\text { interval }\end{array}$ & $\begin{array}{l}\text { Number of } \\
\text { Yrs Lived }\end{array}$ & $\begin{array}{l}\text { Total No. of } \\
\text { Yrs Lived } \\
\text { beyond }\end{array}$ & $\begin{array}{l}\text { Expectation } \\
\text { of life }\end{array}$ & $95 \%$ Cor & ce Limits \\
\hline $\begin{array}{l}\text { (in years) } \\
x \text { to } x+1\end{array}$ & $\begin{array}{c}\text { Rate } \\
\mathrm{Mi}\end{array}$ & $\begin{array}{c}\text { interval } \\
\text { ai }\end{array}$ & $\begin{array}{c}\text { in interval } \\
\text { qi }\end{array}$ & $\begin{array}{c}\text { of life } \\
\text { li }\end{array}$ & $\begin{array}{c}\text { in interval } \\
\mathrm{Li}\end{array}$ & $\begin{array}{c}\text { age } x_{i} \\
T i\end{array}$ & $\begin{array}{c}\text { at age } x_{i} \\
\text { ei }\end{array}$ & $\begin{array}{c}\text { Lower } \\
\text { Limit }\end{array}$ & $\begin{array}{c}\text { Upper } \\
\text { Limit }\end{array}$ \\
\hline $0-1$ & 0.0083 & 0.09 & 0.0082 & 100000 & 99253 & 7556995 & 75.57 & 72.30 & 78.84 \\
\hline $1-5$ & 0.0010 & 0.41 & 0.0041 & 99180 & 395748 & 7457742 & 75.19 & 72.19 & 78.20 \\
\hline $5-10$ & 0.0005 & 0.44 & 0.0027 & 98768 & 493092 & 7061993 & 71.50 & 68.63 & 74.37 \\
\hline $10-15$ & 0.0004 & 0.54 & 0.0019 & 98500 & 492077 & 6568902 & 66.69 & 63.90 & 69.48 \\
\hline $15-20$ & 0.0013 & 0.59 & 0.0067 & 98316 & 490224 & 6076824 & 61.81 & 59.07 & 64.55 \\
\hline $20-25$ & 0.0010 & 0.49 & 0.0052 & 97655 & 486972 & 5586600 & 57.21 & 54.62 & 59.79 \\
\hline $25-30$ & 0.0010 & 0.51 & 0.0049 & 97144 & 484556 & 5099628 & 52.50 & 50.02 & 54.97 \\
\hline $30-35$ & 0.0015 & 0.52 & 0.0076 & 96669 & 481590 & 4615072 & 47.74 & 45.36 & 50.13 \\
\hline $35-40$ & 0.0014 & 0.53 & 0.0072 & 95937 & 478075 & 4133482 & 43.09 & 40.82 & 45.35 \\
\hline $40-45$ & 0.0019 & 0.54 & 0.0096 & 95251 & 474146 & 3655407 & 38.38 & 36.20 & 40.55 \\
\hline $45-50$ & 0.0037 & 0.53 & 0.0182 & 94334 & 467630 & 3181262 & 33.72 & 31.64 & 35.80 \\
\hline $50-55$ & 0.0052 & 0.53 & 0.0259 & 92615 & 457439 & 2713632 & 29.30 & 27.37 & 31.23 \\
\hline $55-60$ & 0.0076 & 0.52 & 0.0372 & 90216 & 443030 & 2256193 & 25.01 & 23.25 & 26.77 \\
\hline $60-65$ & 0.0128 & 0.52 & 0.0619 & 86861 & 421397 & 1813162 & 20.87 & 19.31 & 22.44 \\
\hline $65-69$ & 0.0109 & 0.51 & 0.0530 & 81482 & 396838 & 1391765 & 17.08 & 15.78 & 18.38 \\
\hline $70-74$ & 0.0219 & 0.52 & 0.1040 & 77167 & 366568 & 994927 & 12.89 & 11.77 & 14.02 \\
\hline $75-79$ & 0.0424 & 0.51 & 0.1922 & 69140 & 313145 & 628359 & 9.09 & 8.19 & 9.99 \\
\hline $80-84$ & 0.0854 & 0.50 & 0.3518 & 55853 & 230138 & 315214 & 5.64 & 5.04 & 6.25 \\
\hline $85+$ & 0.1148 & 0.47 & 1.0000 & 36203 & 85076 & 85076 & 2.35 & 2.35 & 2.35 \\
\hline
\end{tabular}

Note: Eastern Region: Atlantic, Quebec, Ontario and Manitoba

Source: Development \& Demographic Methods Section, Demography Division, Statistics Canada, 2003. 
Ravi B. P. Verma, Margaret Michalowski and R. Pierre Gauvin

Appendix Table 11. Abridged Life Table for Registered Indians, Western Region, Canada, 1976-1980

\begin{tabular}{|c|c|c|c|c|c|c|c|c|c|}
\hline $\begin{array}{c}\text { Male } \\
\text { Age interval }\end{array}$ & Death & $\begin{array}{l}\text { Fraction } \\
\text { of last age }\end{array}$ & $\begin{array}{l}\text { Probability } \\
\text { of dying }\end{array}$ & $\begin{array}{l}\text { No of living } \\
\text { at age } \\
\text { interval }\end{array}$ & $\begin{array}{l}\text { Number of } \\
\text { Yrs Lived }\end{array}$ & $\begin{array}{c}\text { Total No. of } \\
\text { Yrs Lived } \\
\text { beyond }\end{array}$ & $\begin{array}{l}\text { Expectation } \\
\text { of life }\end{array}$ & \multicolumn{2}{|c|}{ 95\% Confidence Limits } \\
\hline $\begin{array}{l}\text { (in years) } \\
x \text { to } x+1\end{array}$ & $\begin{array}{c}\text { Rate } \\
\text { Mi }\end{array}$ & $\begin{array}{c}\text { interval } \\
\text { ai }\end{array}$ & $\begin{array}{c}\text { in interval } \\
\text { qi }\end{array}$ & $\begin{array}{l}\text { of life } \\
\text { li }\end{array}$ & $\begin{array}{c}\text { in interval } \\
\mathrm{Li}\end{array}$ & $\begin{array}{c}\text { age } x_{i} \\
T i\end{array}$ & $\begin{array}{c}\text { at age } x_{i} \\
\text { ei }\end{array}$ & $\begin{array}{c}\text { Lower } \\
\text { Limit }\end{array}$ & $\begin{array}{l}\text { Upper } \\
\text { Limit }\end{array}$ \\
\hline $0-1$ & 0.0400 & 0.15 & 0.0387 & 100000 & 96713 & 5778663 & 57.79 & 53.03 & 62.54 \\
\hline $1-5$ & 0.0029 & 0.39 & 0.0114 & 96133 & 381860 & 5681950 & 59.11 & 54.76 & 63.45 \\
\hline $5-10$ & 0.0012 & 0.47 & 0.0060 & 95038 & 473683 & 5300090 & 55.77 & 51.55 & 59.99 \\
\hline $10-15$ & 0.0014 & 0.55 & 0.0069 & 94470 & 470886 & 4826407 & 51.09 & 46.93 & 55.25 \\
\hline $15-20$ & 0.0056 & 0.56 & 0.0278 & 93820 & 463368 & 4355521 & 46.42 & 42.32 & 50.53 \\
\hline $20-25$ & 0.0091 & 0.50 & 0.0443 & 91215 & 445965 & 3892153 & 42.67 & 38.73 & 46.61 \\
\hline $25-30$ & 0.0076 & 0.51 & 0.0374 & 87171 & 427857 & 3446188 & 39.53 & 35.86 & 43.21 \\
\hline $30-35$ & 0.0087 & 0.53 & 0.0428 & 83907 & 411089 & 3018331 & 35.97 & 32.50 & 39.44 \\
\hline $35-40$ & 0.0108 & 0.53 & 0.0528 & 80313 & 391602 & 2607242 & 32.46 & 29.20 & 35.73 \\
\hline $40-45$ & 0.0117 & 0.53 & 0.0572 & 76073 & 370149 & 2215640 & 29.13 & 26.08 & 32.17 \\
\hline $45-50$ & 0.0146 & 0.54 & 0.0709 & 71725 & 346938 & 1845492 & 25.73 & 22.90 & 28.56 \\
\hline $50-55$ & 0.0155 & 0.52 & 0.0748 & 66643 & 321249 & 1498554 & 22.49 & 19.89 & 25.08 \\
\hline $55-60$ & 0.0242 & 0.53 & 0.1143 & 61656 & 291724 & 1177305 & 19.09 & 16.70 & 21.49 \\
\hline $60-65$ & 0.0261 & 0.52 & 0.1230 & 54610 & 256928 & 885581 & 16.22 & 14.09 & 18.34 \\
\hline $65-69$ & 0.0313 & 0.52 & 0.1457 & 47892 & 222713 & 628653 & 13.13 & 11.25 & 15.00 \\
\hline $70-74$ & 0.0546 & 0.51 & 0.2407 & 40914 & 180440 & 405940 & 9.92 & 8.27 & 11.58 \\
\hline $75-79$ & 0.0826 & 0.50 & 0.3423 & 31066 & 128743 & 225500 & 7.26 & 5.87 & 8.65 \\
\hline $80-84$ & 0.1420 & 0.48 & 0.5184 & 20432 & 74619 & 96757 & 4.74 & 3.68 & 5.79 \\
\hline $85+$ & 0.1631 & 0.45 & 1.0000 & 9839 & 22139 & 22139 & 2.25 & 2.25 & 2.25 \\
\hline $\begin{array}{l}\text { Female } \\
\text { Age interval }\end{array}$ & Death & $\begin{array}{l}\text { Fraction } \\
\text { of last age }\end{array}$ & $\begin{array}{l}\text { Probability } \\
\text { of dying }\end{array}$ & $\begin{array}{l}\text { No of living } \\
\text { at age } \\
\text { interval }\end{array}$ & $\begin{array}{l}\text { Number of } \\
\text { Yrs Lived }\end{array}$ & $\begin{array}{l}\text { Total No. of } \\
\text { Yrs Lived } \\
\text { beyond }\end{array}$ & $\begin{array}{l}\text { Expectation } \\
\text { of life }\end{array}$ & $95 \%$ Cor & ce Limits \\
\hline $\begin{array}{l}\text { (in years) } \\
x \text { to } x+1\end{array}$ & $\begin{array}{c}\text { Rate } \\
\mathrm{Mi}\end{array}$ & $\begin{array}{c}\text { interval } \\
\text { ai }\end{array}$ & $\begin{array}{c}\text { in interval } \\
\text { qi }\end{array}$ & $\begin{array}{c}\text { of life } \\
\text { li }\end{array}$ & $\begin{array}{c}\text { in interval } \\
\mathrm{Li}\end{array}$ & $\begin{array}{c}\text { age } x_{i} \\
T i\end{array}$ & $\begin{array}{c}\text { at age } x_{i} \\
\text { ei }\end{array}$ & $\begin{array}{c}\text { Lower } \\
\text { Limit }\end{array}$ & $\begin{array}{l}\text { Upper } \\
\text { Limit }\end{array}$ \\
\hline $0-1$ & 0.0333 & 0.15 & 0.0324 & 100000 & 97249 & 6387477 & 63.87 & 59.34 & 68.40 \\
\hline $1-5$ & 0.0020 & 0.39 & 0.0082 & 96764 & 385132 & 6290228 & 65.01 & 60.96 & 69.05 \\
\hline $5-10$ & 0.0009 & 0.47 & 0.0044 & 95975 & 478761 & 5905096 & 61.53 & 57.62 & 65.44 \\
\hline $10-15$ & 0.0006 & 0.55 & 0.0032 & 95554 & 477077 & 5426335 & 56.79 & 52.94 & 60.63 \\
\hline $15-20$ & 0.0028 & 0.56 & 0.0139 & 95246 & 473318 & 4949257 & 51.96 & 48.15 & 55.77 \\
\hline $20-25$ & 0.0041 & 0.50 & 0.0202 & 93923 & 464876 & 4475939 & 47.66 & 43.98 & 51.33 \\
\hline $25-30$ & 0.0046 & 0.51 & 0.0227 & 92028 & 455015 & 4011064 & 43.59 & 40.08 & 47.09 \\
\hline $30-35$ & 0.0058 & 0.53 & 0.0287 & 89937 & 443613 & 3556049 & 39.54 & 36.20 & 42.88 \\
\hline $35-40$ & 0.0086 & 0.53 & 0.0421 & 87354 & 428120 & 3112435 & 35.63 & 32.47 & 38.79 \\
\hline $40-45$ & 0.0087 & 0.53 & 0.0427 & 83673 & 409966 & 2684316 & 32.08 & 29.15 & 35.01 \\
\hline $45-50$ & 0.0123 & 0.54 & 0.0600 & 80099 & 389445 & 2274350 & 28.39 & 25.67 & 31.12 \\
\hline $50-55$ & 0.0134 & 0.52 & 0.0649 & 75295 & 364752 & 1884905 & 25.03 & 22.56 & 27.51 \\
\hline $55-60$ & 0.0159 & 0.53 & 0.0766 & 70410 & 339377 & 1520153 & 21.59 & 19.36 & 23.82 \\
\hline $60-65$ & 0.0212 & 0.52 & 0.1007 & 65017 & 309373 & 1180776 & 18.16 & 16.18 & 20.14 \\
\hline $65-69$ & 0.0223 & 0.52 & 0.1058 & 58471 & 277512 & 871403 & 14.90 & 13.21 & 16.60 \\
\hline $70-74$ & 0.0382 & 0.51 & 0.1747 & 52287 & 239059 & 593891 & 11.36 & 9.90 & 12.82 \\
\hline $75-79$ & 0.0573 & 0.50 & 0.2505 & 43154 & 188751 & 354832 & 8.22 & 7.06 & 9.39 \\
\hline $80-84$ & 0.1128 & 0.48 & 0.4362 & 32346 & 125047 & 166081 & 5.13 & 4.31 & 5.96 \\
\hline $85+$ & 0.1517 & 0.45 & 1.0000 & 18237 & 41034 & 41034 & 2.25 & 2.25 & 2.25 \\
\hline
\end{tabular}

Note: Western Region: N.W.T., Saskatchewan, Alberta, Yukon, and B.C.

Source: Development \& Demographic Methods Section, Demography Division, Statistics Canada, 2003. 
Abridged Life Tables for Registered Indians in Canada, 1976-1980 to 1996-2000

Appendix Table 12. Abridged Life Table for Registered Indians, Western Region, Canada, 1981-1985

\begin{tabular}{|c|c|c|c|c|c|c|c|c|c|}
\hline \multirow{2}{*}{$\begin{array}{c}\text { Male } \\
\text { Age interval } \\
\text { (in years) } \\
x \text { to } x+1\end{array}$} & \multirow{2}{*}{$\begin{array}{l}\text { Death } \\
\text { Rate } \\
\text { Mi }\end{array}$} & \multirow{2}{*}{$\begin{array}{c}\text { Fraction } \\
\text { of last age } \\
\text { interval } \\
\text { ai } \\
\end{array}$} & \multirow{2}{*}{$\begin{array}{c}\text { Probability } \\
\text { of dying } \\
\text { in interval } \\
\text { qi }\end{array}$} & \multirow{2}{*}{$\begin{array}{l}\text { No of living } \\
\text { at age } \\
\text { interval } \\
\text { of life } \\
\text { li }\end{array}$} & \multirow{2}{*}{$\begin{array}{c}\text { Number of } \\
\text { Yrs Lived } \\
\text { in interval } \\
\mathrm{Li}\end{array}$} & \multirow{2}{*}{$\begin{array}{c}\text { Total No. of } \\
\text { Yrs Lived } \\
\text { beyond } \\
\text { age } x_{i} \\
T i\end{array}$} & \multirow{2}{*}{$\begin{array}{c}\text { Expectation } \\
\text { of life } \\
\text { at age } x_{i} \\
\text { ei }\end{array}$} & \multicolumn{2}{|c|}{ 95\% Confidence Limits } \\
\hline & & & & & & & & $\begin{array}{c}\text { Lower } \\
\text { Limit }\end{array}$ & $\begin{array}{l}\text { Upper } \\
\text { Limit }\end{array}$ \\
\hline $0-1$ & 0.0277 & 0.15 & 0.0271 & 100000 & 97700 & 6074738 & 60.75 & 56.38 & 65.12 \\
\hline $1-5$ & 0.0018 & 0.41 & 0.0071 & 97294 & 387546 & 5977038 & 61.43 & 57.43 & 65.44 \\
\hline $5-10$ & 0.0006 & 0.44 & 0.0032 & 96603 & 482149 & 5589492 & 57.86 & 53.96 & 61.77 \\
\hline $10-15$ & 0.0009 & 0.54 & 0.0047 & 96294 & 480433 & 5107342 & 53.04 & 49.17 & 56.91 \\
\hline $15-20$ & 0.0044 & 0.59 & 0.0217 & 95843 & 474949 & 4626910 & 48.28 & 44.45 & 52.10 \\
\hline $20-25$ & 0.0070 & 0.49 & 0.0345 & 93761 & 460568 & 4151961 & 44.28 & 40.63 & 47.94 \\
\hline $25-30$ & 0.0065 & 0.51 & 0.0321 & 90530 & 445539 & 3691393 & 40.78 & 37.37 & 44.18 \\
\hline $30-35$ & 0.0072 & 0.52 & 0.0353 & 87627 & 430711 & 3245854 & 37.04 & 33.85 & 40.23 \\
\hline $35-40$ & 0.0065 & 0.53 & 0.0322 & 84533 & 416278 & 2815142 & 33.30 & 30.32 & 36.28 \\
\hline $40-45$ & 0.0102 & 0.54 & 0.0497 & 81815 & 399724 & 2398864 & 29.32 & 26.50 & 32.14 \\
\hline $45-50$ & 0.0125 & 0.53 & 0.0607 & 77749 & 377657 & 1999140 & 25.71 & 23.09 & 28.34 \\
\hline $50-55$ & 0.0159 & 0.53 & 0.0767 & 73030 & 351992 & 1621483 & 22.20 & 19.78 & 24.63 \\
\hline $55-60$ & 0.0214 & 0.52 & 0.1017 & 67431 & 320701 & 1269492 & 18.83 & 16.60 & 21.05 \\
\hline $60-65$ & 0.0266 & 0.52 & 0.1251 & 60576 & 284694 & 948791 & 15.66 & 13.65 & 17.67 \\
\hline $65-69$ & 0.0377 & 0.53 & 0.1733 & 52999 & 243408 & 664097 & 12.53 & 10.73 & 14.33 \\
\hline $70-74$ & 0.0605 & 0.53 & 0.2647 & 43813 & 191812 & 420689 & 9.60 & 7.99 & 11.21 \\
\hline $75-79$ & 0.0951 & 0.52 & 0.3871 & 32216 & 131147 & 228877 & 7.10 & 5.71 & 8.50 \\
\hline $80-84$ & 0.1315 & 0.50 & 0.4949 & 19744 & 74293 & 97730 & 4.95 & 3.88 & 6.02 \\
\hline $85+$ & 0.1694 & 0.47 & 1.0000 & 9973 & 23436 & 23436 & 2.35 & 2.35 & 2.35 \\
\hline $\begin{array}{c}\text { Female } \\
\text { Age interval }\end{array}$ & Death & $\begin{array}{l}\text { Fraction } \\
\text { of last age }\end{array}$ & $\begin{array}{l}\text { Probability } \\
\text { of dying }\end{array}$ & $\begin{array}{l}\text { No of living } \\
\text { at age } \\
\text { interval }\end{array}$ & $\begin{array}{l}\text { Number of } \\
\text { Yrs Lived }\end{array}$ & $\begin{array}{c}\text { Total No. of } \\
\text { Yrs Lived } \\
\text { beyond }\end{array}$ & $\begin{array}{l}\text { Expectation } \\
\text { of life }\end{array}$ & $95 \%$ Cor & ce Limits \\
\hline $\begin{array}{l}\text { (in years) } \\
x \text { to } x+1\end{array}$ & $\begin{array}{c}\text { Rate } \\
\mathrm{Mi}\end{array}$ & $\begin{array}{c}\text { interval } \\
\text { ai }\end{array}$ & $\begin{array}{c}\text { in interval } \\
\text { qi }\end{array}$ & $\begin{array}{l}\text { of life } \\
\text { li }\end{array}$ & $\begin{array}{c}\text { in interval } \\
\mathrm{Li}\end{array}$ & $\begin{array}{c}\text { age } x_{i} \\
T i\end{array}$ & $\begin{array}{c}\text { at age } x_{i} \\
\text { ei }\end{array}$ & $\begin{array}{c}\text { Lower } \\
\text { Limit }\end{array}$ & $\begin{array}{l}\text { Upper } \\
\text { Limit }\end{array}$ \\
\hline $0-1$ & 0.0222 & 0.15 & 0.0218 & 100000 & 98144 & 6730634 & 67.31 & 63.20 & 71.41 \\
\hline $1-5$ & 0.0014 & 0.39 & 0.0056 & 97816 & 389926 & 6632490 & 67.81 & 64.12 & 71.49 \\
\hline $5-10$ & 0.0004 & 0.47 & 0.0018 & 97268 & 485862 & 6242564 & 64.18 & 60.61 & 67.75 \\
\hline $10-15$ & 0.0006 & 0.55 & 0.0031 & 97088 & 484753 & 5756702 & 59.29 & 55.76 & 62.83 \\
\hline $15-20$ & 0.0018 & 0.56 & 0.0089 & 96783 & 482012 & 5271949 & 54.47 & 50.98 & 57.96 \\
\hline $20-25$ & 0.0027 & 0.50 & 0.0132 & 95918 & 476414 & 4789937 & 49.94 & 46.56 & 53.32 \\
\hline $25-30$ & 0.0038 & 0.51 & 0.0186 & 94648 & 468927 & 4313523 & 45.57 & 42.34 & 48.81 \\
\hline $30-35$ & 0.0047 & 0.53 & 0.0234 & 92888 & 459338 & 3844595 & 41.39 & 38.32 & 44.46 \\
\hline $35-40$ & 0.0052 & 0.53 & 0.0258 & 90717 & 448092 & 3385257 & 37.32 & 34.44 & 40.20 \\
\hline $40-45$ & 0.0075 & 0.53 & 0.0369 & 88380 & 434233 & 2937165 & 33.23 & 30.53 & 35.94 \\
\hline $45-50$ & 0.0074 & 0.54 & 0.0365 & 85118 & 418434 & 2502932 & 29.41 & 26.91 & 31.90 \\
\hline $50-55$ & 0.0094 & 0.52 & 0.0460 & 82007 & 400978 & 2084498 & 25.42 & 23.10 & 27.74 \\
\hline $55-60$ & 0.0193 & 0.53 & 0.0924 & 78233 & 374170 & 1683520 & 21.52 & 19.37 & 23.67 \\
\hline $60-65$ & 0.0161 & 0.52 & 0.0773 & 71001 & 341829 & 1309350 & 18.44 & 16.58 & 20.30 \\
\hline $65-69$ & 0.0242 & 0.52 & 0.1143 & 65511 & 309586 & 967521 & 14.77 & 13.12 & 16.42 \\
\hline $70-74$ & 0.0390 & 0.51 & 0.1781 & 58024 & 264799 & 657936 & 11.34 & 9.91 & 12.77 \\
\hline $75-79$ & 0.0668 & 0.50 & 0.2864 & 47689 & 204303 & 393137 & 8.24 & 7.07 & 9.42 \\
\hline $80-84$ & 0.0858 & 0.48 & 0.3508 & 34032 & 139122 & 188833 & 5.55 & 4.77 & 6.33 \\
\hline $85+$ & 0.1500 & 0.45 & 1.0000 & 22094 & 49712 & 49712 & 2.25 & 2.25 & 2.25 \\
\hline
\end{tabular}

Note: Western Region: N.W.T., Saskatchewan, Alberta, Yukon, and B.C.

Source: Development \& Demographic Methods Section, Demography Division, Statistics Canada, 2003. 
Ravi B. P. Verma, Margaret Michalowski and R. Pierre Gauvin

\begin{tabular}{|c|c|c|c|c|c|c|c|c|c|}
\hline \multirow{3}{*}{$\begin{array}{c}\text { Age interval } \\
\text { (in years) } \\
x \text { to } x+1\end{array}$} & \multirow{3}{*}{$\begin{array}{c}\text { Death } \\
\text { Rate } \\
\text { Mi }\end{array}$} & \multirow{3}{*}{$\begin{array}{c}\text { Fraction } \\
\text { of last age } \\
\text { interval } \\
\text { ai }\end{array}$} & \multirow{3}{*}{$\begin{array}{c}\text { Probability } \\
\text { of dying } \\
\text { in interval } \\
\text { qi }\end{array}$} & \multirow{3}{*}{$\begin{array}{l}\text { No of living } \\
\text { at age } \\
\text { interval } \\
\text { of life } \\
\text { li }\end{array}$} & \multirow{3}{*}{$\begin{array}{c}\text { Number of } \\
\text { Yrs Lived } \\
\text { in interval } \\
\mathrm{Li}\end{array}$} & \multirow{3}{*}{$\begin{array}{c}\text { Total No. of } \\
\text { Yrs Lived } \\
\text { beyond } \\
\text { age } x_{i} \\
T i\end{array}$} & \multirow{3}{*}{$\begin{array}{c}\text { Expectation } \\
\text { of life } \\
\text { at age } x_{i} \\
\text { ei }\end{array}$} & \multicolumn{2}{|c|}{ 95\% Confidence Limits } \\
\hline & & & & & & & & Lower & Upper \\
\hline & & & & & & & & Limit & Limit \\
\hline $0-1$ & 0.0142 & 0.09 & 0.0140 & 100000 & 98722 & 6470109 & 64.70 & 60.67 & 68.73 \\
\hline $1-5$ & 0.0013 & 0.41 & 0.0051 & 98596 & 393192 & 6371386 & 64.62 & 60.83 & 68.41 \\
\hline $5-10$ & 0.0006 & 0.44 & 0.0028 & 98091 & 489686 & 5978195 & 60.95 & 57.24 & 64.65 \\
\hline $10-15$ & 0.0008 & 0.54 & 0.0040 & 97816 & 488175 & 5488509 & 56.11 & 52.45 & 59.77 \\
\hline $15-20$ & 0.0038 & 0.59 & 0.0188 & 97422 & 483351 & 5000334 & 51.33 & 47.71 & 54.94 \\
\hline $20-25$ & 0.0050 & 0.49 & 0.0248 & 95588 & 471902 & 4516983 & 47.25 & 43.83 & 50.68 \\
\hline $25-30$ & 0.0048 & 0.51 & 0.0236 & 93220 & 460715 & 4045081 & 43.39 & 40.20 & 46.58 \\
\hline $30-35$ & 0.0052 & 0.52 & 0.0258 & 91022 & 449471 & 3584366 & 39.38 & 36.39 & 42.37 \\
\hline $35-40$ & 0.0052 & 0.53 & 0.0256 & 88673 & 438032 & 3134895 & 35.35 & 32.56 & 38.15 \\
\hline $40-45$ & 0.0072 & 0.54 & 0.0354 & 86404 & 424989 & 2696863 & 31.21 & 28.57 & 33.85 \\
\hline $45-50$ & 0.0096 & 0.53 & 0.0469 & 83347 & 407538 & 2271874 & 27.26 & 24.80 & 29.72 \\
\hline $50-55$ & 0.0122 & 0.53 & 0.0593 & 79434 & 386101 & 1864336 & 23.47 & 21.20 & 25.74 \\
\hline $55-60$ & 0.0162 & 0.52 & 0.0778 & 74724 & 359662 & 1478235 & 19.78 & 17.70 & 21.86 \\
\hline $60-65$ & 0.0252 & 0.52 & 0.1187 & 68908 & 324909 & 1118573 & 16.23 & 14.34 & 18.13 \\
\hline $65-69$ & 0.0321 & 0.51 & 0.1490 & 60728 & 281475 & 793664 & 13.07 & 11.39 & 14.75 \\
\hline $70-74$ & 0.0560 & 0.52 & 0.2470 & 51681 & 227770 & 512188 & 9.91 & 8.43 & 11.40 \\
\hline $75-79$ & 0.0852 & 0.51 & 0.3524 & 38917 & 160982 & 284418 & 7.31 & 6.05 & 8.57 \\
\hline $80-84$ & 0.1353 & 0.50 & 0.5056 & 25202 & 94155 & 123436 & 4.90 & 3.95 & 5.84 \\
\hline $85+$ & 0.1568 & 0.47 & 1.0000 & 12460 & 29281 & 29281 & 2.35 & 2.35 & 2.35 \\
\hline $\begin{array}{c}\text { Female } \\
\text { Age interval }\end{array}$ & Death & $\begin{array}{l}\text { Fraction } \\
\text { of last age }\end{array}$ & $\begin{array}{l}\text { Probability } \\
\text { of dying }\end{array}$ & $\begin{array}{l}\text { No of living } \\
\text { at age } \\
\text { interval }\end{array}$ & $\begin{array}{l}\text { Number of } \\
\text { Yrs Lived }\end{array}$ & $\begin{array}{c}\text { Total No. of } \\
\text { Yrs Lived } \\
\text { beyond }\end{array}$ & $\begin{array}{l}\text { Expectation } \\
\text { of life }\end{array}$ & $95 \%$ Cor & ce Limits \\
\hline $\begin{array}{c}\text { (in years) } \\
x \text { to } x+1\end{array}$ & $\begin{array}{c}\text { Rate } \\
\mathrm{Mi}\end{array}$ & $\begin{array}{c}\text { interval } \\
\text { ai }\end{array}$ & $\begin{array}{c}\text { in interval } \\
\text { qi }\end{array}$ & $\begin{array}{c}\text { of life } \\
\text { li }\end{array}$ & $\begin{array}{c}\text { in interval } \\
\mathrm{Li}\end{array}$ & $\begin{array}{c}\text { age } x_{i} \\
T i\end{array}$ & $\begin{array}{c}\text { at age } x_{i} \\
\text { ei }\end{array}$ & $\begin{array}{c}\text { Lower } \\
\text { Limit }\end{array}$ & $\begin{array}{l}\text { Upper } \\
\text { Limit }\end{array}$ \\
\hline $0-1$ & 0.0139 & 0.09 & 0.0137 & 100000 & 98751 & 7075824 & 70.76 & 67.07 & 74.45 \\
\hline $1-5$ & 0.0008 & 0.41 & 0.0031 & 98627 & 393788 & 6977073 & 70.74 & 67.39 & 74.10 \\
\hline $5-10$ & 0.0006 & 0.44 & 0.0029 & 98322 & 490800 & 6583285 & 66.96 & 63.68 & 70.23 \\
\hline $10-15$ & 0.0006 & 0.54 & 0.0031 & 98033 & 489461 & 6092484 & 62.15 & 58.93 & 65.36 \\
\hline $15-20$ & 0.0016 & 0.59 & 0.0079 & 97727 & 487051 & 5603023 & 57.33 & 54.18 & 60.49 \\
\hline $20-25$ & 0.0020 & 0.49 & 0.0101 & 96955 & 482280 & 5115972 & 52.77 & 49.74 & 55.79 \\
\hline $25-30$ & 0.0021 & 0.51 & 0.0105 & 95977 & 477403 & 4633692 & 48.28 & 45.40 & 51.16 \\
\hline $30-35$ & 0.0029 & 0.52 & 0.0144 & 94964 & 471546 & 4156289 & 43.77 & 41.01 & 46.52 \\
\hline $35-40$ & 0.0039 & 0.53 & 0.0194 & 93599 & 463740 & 3684743 & 39.37 & 36.76 & 41.97 \\
\hline $40-45$ & 0.0044 & 0.54 & 0.0218 & 91788 & 454335 & 3221002 & 35.09 & 32.66 & 37.52 \\
\hline $45-50$ & 0.0064 & 0.53 & 0.0316 & 89786 & 442259 & 2766667 & 30.81 & 28.54 & 33.08 \\
\hline $50-55$ & 0.0080 & 0.53 & 0.0391 & 86948 & 426742 & 2324408 & 26.73 & 24.66 & 28.81 \\
\hline $55-60$ & 0.0099 & 0.52 & 0.0482 & 83545 & 408061 & 1897666 & 22.71 & 20.83 & 24.60 \\
\hline $60-65$ & 0.0154 & 0.52 & 0.0740 & 79519 & 383463 & 1489605 & 18.73 & 17.04 & 20.43 \\
\hline $65-69$ & 0.0174 & 0.51 & 0.0834 & 73631 & 353115 & 1106142 & 15.02 & 13.55 & 16.50 \\
\hline $70-74$ & 0.0397 & 0.52 & 0.1812 & 67492 & 308110 & 753026 & 11.16 & 9.85 & 12.46 \\
\hline $75-79$ & 0.0695 & 0.51 & 0.2968 & 55263 & 236125 & 444916 & 8.05 & 6.97 & 9.13 \\
\hline $80-84$ & 0.1024 & 0.50 & 0.4076 & 38859 & 154696 & 208792 & 5.37 & 4.62 & 6.12 \\
\hline $85+$ & 0.1424 & 0.47 & 1.0000 & 23019 & 54096 & 54096 & 2.35 & 2.35 & 2.35 \\
\hline
\end{tabular}

Note: Western Region: N.W.T., Saskatchewan, Alberta, Yukon, and B.C.

Source: Development \& Demographic Methods Section, Demography Division, Statistics Canada, 2003. 
Abridged Life Tables for Registered Indians in Canada, 1976-1980 to 1996-2000

Appendix Table 14. Abridged Life Table for Registered Indians, Western Region, Canada, 1991-1995

\begin{tabular}{|c|c|c|c|c|c|c|c|c|c|}
\hline $\begin{array}{c}\text { Male } \\
\text { Age interval }\end{array}$ & Death & $\begin{array}{l}\text { Fraction } \\
\text { of last age }\end{array}$ & $\begin{array}{l}\text { Probability } \\
\text { of dying }\end{array}$ & $\begin{array}{l}\text { No of living } \\
\text { at age } \\
\text { interval }\end{array}$ & $\begin{array}{l}\text { Number of } \\
\text { Yrs Lived }\end{array}$ & $\begin{array}{l}\text { Total No. of } \\
\text { Yrs Lived } \\
\text { beyond }\end{array}$ & $\begin{array}{l}\text { Expectation } \\
\text { of life }\end{array}$ & \multicolumn{2}{|c|}{ 95\% Confidence Limits } \\
\hline $\begin{array}{l}\text { (in years) } \\
x \text { to } x+1\end{array}$ & $\begin{array}{c}\text { Rate } \\
\text { Mi }\end{array}$ & $\begin{array}{c}\text { interval } \\
\text { ai }\end{array}$ & $\begin{array}{c}\text { in interval } \\
\text { qi }\end{array}$ & $\begin{array}{c}\text { of life } \\
\text { li }\end{array}$ & $\begin{array}{c}\text { in interval } \\
\mathrm{Li}\end{array}$ & $\begin{array}{c}\text { age } x_{i} \\
T i\end{array}$ & $\begin{array}{c}\text { at age } x_{i} \\
\text { ei }\end{array}$ & $\begin{array}{c}\text { Lower } \\
\text { Limit }\end{array}$ & $\begin{array}{l}\text { Upper } \\
\text { Limit }\end{array}$ \\
\hline $1-5$ & 0.0009 & 0.41 & 0.0036 & 98688 & 393903 & 6502311 & 65.89 & 62.24 & 69.53 \\
\hline $5-10$ & 0.0005 & 0.44 & 0.0026 & 98328 & 490939 & 6108409 & 62.12 & 58.54 & 65.70 \\
\hline $10-15$ & 0.0005 & 0.54 & 0.0026 & 98077 & 489807 & 5617470 & 57.28 & 53.74 & 60.81 \\
\hline $15-20$ & 0.0031 & 0.59 & 0.0152 & 97825 & 486070 & 5127663 & 52.42 & 48.91 & 55.92 \\
\hline $20-25$ & 0.0042 & 0.49 & 0.0206 & 96334 & 476611 & 4641594 & 48.18 & 44.85 & 51.52 \\
\hline $25-30$ & 0.0046 & 0.51 & 0.0230 & 94350 & 466437 & 4164983 & 44.14 & 41.02 & 47.27 \\
\hline $30-35$ & 0.0041 & 0.52 & 0.0205 & 92182 & 456377 & 3698546 & 40.12 & 37.21 & 43.04 \\
\hline $35-40$ & 0.0055 & 0.53 & 0.0273 & 90294 & 445676 & 3242169 & 35.91 & 33.15 & 38.66 \\
\hline $40-45$ & 0.0063 & 0.54 & 0.0312 & 87829 & 432834 & 2796493 & 31.84 & 29.27 & 34.41 \\
\hline $45-50$ & 0.0087 & 0.53 & 0.0428 & 85085 & 416869 & 2363659 & 27.78 & 25.38 & 30.18 \\
\hline $50-55$ & 0.0104 & 0.53 & 0.0510 & 81444 & 397463 & 1946790 & 23.90 & 21.69 & 26.12 \\
\hline $55-60$ & 0.0171 & 0.52 & 0.0821 & 77292 & 371230 & 1549327 & 20.05 & 18.00 & 22.09 \\
\hline $60-65$ & 0.0229 & 0.52 & 0.1084 & 70946 & 336276 & 1178097 & 16.61 & 14.78 & 18.44 \\
\hline $65-69$ & 0.0275 & 0.51 & 0.1288 & 63257 & 296326 & 841821 & 13.31 & 11.70 & 14.92 \\
\hline $70-74$ & 0.0534 & 0.52 & 0.2366 & 55111 & 244261 & 545495 & 9.90 & 8.47 & 11.33 \\
\hline $75-79$ & 0.0937 & 0.51 & 0.3809 & 42072 & 171095 & 301234 & 7.16 & 5.92 & 8.40 \\
\hline $80-84$ & 0.1281 & 0.50 & 0.4852 & 26045 & 98631 & 130138 & 5.00 & 4.07 & 5.93 \\
\hline $85+$ & 0.1807 & 0.47 & 1.0000 & 13407 & 31507 & 31507 & 2.35 & 2.35 & 2.35 \\
\hline $\begin{array}{c}\text { Female } \\
\text { Age interval }\end{array}$ & Death & $\begin{array}{l}\text { Fraction } \\
\text { of last age }\end{array}$ & $\begin{array}{l}\text { Probability } \\
\text { of dying }\end{array}$ & $\begin{array}{l}\text { No of living } \\
\text { at age } \\
\text { interval }\end{array}$ & $\begin{array}{l}\text { Number of } \\
\text { Yrs Lived }\end{array}$ & $\begin{array}{l}\text { Total No. of } \\
\text { Yrs Lived } \\
\text { beyond }\end{array}$ & $\begin{array}{l}\text { Expectation } \\
\text { of life }\end{array}$ & $95 \%$ Co & ce Limits \\
\hline $\begin{array}{l}\text { (in years) } \\
x \text { to } x+1\end{array}$ & $\begin{array}{c}\text { Rate } \\
\mathrm{Mi}\end{array}$ & $\begin{array}{c}\text { interval } \\
\text { ai }\end{array}$ & $\begin{array}{c}\text { in interval } \\
\text { qi }\end{array}$ & $\begin{array}{c}\text { of life } \\
\text { li }\end{array}$ & $\begin{array}{c}\text { in interval } \\
\mathrm{Li}\end{array}$ & $\begin{array}{c}\text { age } x_{i} \\
T i\end{array}$ & $\begin{array}{c}\text { at age } x_{i} \\
\text { ei }\end{array}$ & $\begin{array}{c}\text { Lower } \\
\text { Limit }\end{array}$ & $\begin{array}{l}\text { Upper } \\
\text { Limit }\end{array}$ \\
\hline $0-1$ & 0.0118 & 0.09 & 0.0116 & 100000 & 98940 & 7241598 & 72.42 & 68.86 & 75.98 \\
\hline $1-5$ & 0.0007 & 0.41 & 0.0028 & 98836 & 394685 & 7142658 & 72.27 & 69.02 & 75.52 \\
\hline $5-10$ & 0.0003 & 0.44 & 0.0016 & 98557 & 492331 & 6747973 & 68.47 & 65.30 & 71.64 \\
\hline $10-15$ & 0.0005 & 0.54 & 0.0024 & 98395 & 491430 & 6255642 & 63.58 & 60.45 & 66.71 \\
\hline $15-20$ & 0.0015 & 0.59 & 0.0073 & 98158 & 489331 & 5764211 & 58.72 & 55.64 & 61.81 \\
\hline $20-25$ & 0.0017 & 0.49 & 0.0086 & 97446 & 485097 & 5274880 & 54.13 & 51.17 & 57.09 \\
\hline $25-30$ & 0.0021 & 0.51 & 0.0106 & 96610 & 480540 & 4789783 & 49.58 & 46.76 & 52.40 \\
\hline $30-35$ & 0.0024 & 0.52 & 0.0121 & 95586 & 475147 & 4309243 & 45.08 & 42.40 & 47.76 \\
\hline $35-40$ & 0.0033 & 0.53 & 0.0162 & 94426 & 468546 & 3834096 & 40.60 & 38.07 & 43.14 \\
\hline $40-45$ & 0.0038 & 0.54 & 0.0189 & 92901 & 460465 & 3365550 & 36.23 & 33.85 & 38.61 \\
\hline $45-50$ & 0.0053 & 0.53 & 0.0264 & 91145 & 450074 & 2905085 & 31.87 & 29.65 & 34.10 \\
\hline $50-55$ & 0.0072 & 0.53 & 0.0354 & 88740 & 436311 & 2455011 & 27.67 & 25.62 & 29.71 \\
\hline $55-60$ & 0.0097 & 0.52 & 0.0474 & 85596 & 418232 & 2018700 & 23.58 & 21.73 & 25.44 \\
\hline $60-65$ & 0.0154 & 0.52 & 0.0741 & 81535 & 393169 & 1600468 & 19.63 & 17.99 & 21.27 \\
\hline $65-69$ & 0.0127 & 0.51 & 0.0618 & 75491 & 366031 & 1207299 & 15.99 & 14.62 & 17.36 \\
\hline $70-74$ & 0.0272 & 0.52 & 0.1275 & 70828 & 332462 & 841268 & 11.88 & 10.68 & 13.08 \\
\hline $75-79$ & 0.0618 & 0.51 & 0.2684 & 61796 & 268340 & 508806 & 8.23 & 7.24 & 9.23 \\
\hline $80-84$ & 0.1059 & 0.50 & 0.4187 & 45208 & 178715 & 240466 & 5.32 & 4.62 & 6.02 \\
\hline $85+$ & 0.1824 & 0.47 & 1.0000 & 26277 & 61752 & 61752 & 2.35 & 2.35 & 2.35 \\
\hline
\end{tabular}

Note: Western Region: N.W.T., Saskatchewan, Alberta, Yukon, and B.C.

Source: Development \& Demographic Methods Section, Demography Division, Statistics Canada, 2003. 
Ravi B. P. Verma, Margaret Michalowski and R. Pierre Gauvin

Appendix Table 15. Abridged Life Table for Registered Indians, Western Region, Canada, 1996-2000

\begin{tabular}{|c|c|c|c|c|c|c|c|c|c|}
\hline $\begin{array}{c}\text { Male } \\
\text { Age interval }\end{array}$ & Death & $\begin{array}{l}\text { Fraction } \\
\text { of last age }\end{array}$ & $\begin{array}{l}\text { Probability } \\
\text { of dying }\end{array}$ & $\begin{array}{l}\text { No of living } \\
\text { at age } \\
\text { interval }\end{array}$ & $\begin{array}{l}\text { Number of } \\
\text { Yrs Lived }\end{array}$ & $\begin{array}{c}\text { Total No. of } \\
\text { Yrs Lived } \\
\text { beyond }\end{array}$ & $\begin{array}{l}\text { Expectation } \\
\text { of life }\end{array}$ & \multicolumn{2}{|c|}{ 95\% Confidence Limits } \\
\hline $\begin{array}{l}\text { (in years) } \\
x \text { to } x+1\end{array}$ & $\begin{array}{c}\text { Rate } \\
\mathrm{Mi}\end{array}$ & $\begin{array}{c}\text { interval } \\
\text { ai }\end{array}$ & $\begin{array}{c}\text { in interval } \\
\text { qi }\end{array}$ & $\begin{array}{l}\text { of life } \\
\text { li }\end{array}$ & $\begin{array}{c}\text { in interval } \\
\mathrm{Li}\end{array}$ & $\begin{array}{c}\text { age } x_{i} \\
T i\end{array}$ & $\begin{array}{c}\text { at age } x_{i} \\
\text { ei }\end{array}$ & $\begin{array}{c}\text { Lower } \\
\text { Limit }\end{array}$ & $\begin{array}{l}\text { Upper } \\
\text { Limit }\end{array}$ \\
\hline $0-1$ & 0.0112 & 0.09 & 0.0111 & 100000 & 98989 & 6673530 & 66.74 & 62.88 & 70.59 \\
\hline $1-5$ & 0.0017 & 0.41 & 0.0070 & 98889 & 393930 & 6574541 & 66.48 & 62.84 & 70.12 \\
\hline $5-10$ & 0.0005 & 0.44 & 0.0023 & 98200 & 490359 & 6180611 & 62.94 & 59.43 & 66.44 \\
\hline $10-15$ & 0.0008 & 0.54 & 0.0041 & 97971 & 488942 & 5690252 & 58.08 & 54.62 & 61.54 \\
\hline $15-20$ & 0.0025 & 0.59 & 0.0124 & 97574 & 485392 & 5201310 & 53.31 & 49.90 & 56.71 \\
\hline $20-25$ & 0.0040 & 0.49 & 0.0196 & 96365 & 477015 & 4715918 & 48.94 & 45.68 & 52.20 \\
\hline $25-30$ & 0.0038 & 0.51 & 0.0187 & 94479 & 468061 & 4238903 & 44.87 & 41.82 & 47.91 \\
\hline $30-35$ & 0.0041 & 0.52 & 0.0204 & 92710 & 459012 & 3770842 & 40.67 & 37.82 & 43.53 \\
\hline $35-40$ & 0.0052 & 0.53 & 0.0257 & 90819 & 448617 & 3311830 & 36.47 & 33.78 & 39.15 \\
\hline $40-45$ & 0.0056 & 0.54 & 0.0277 & 88488 & 436806 & 2863213 & 32.36 & 29.86 & 34.86 \\
\hline $45-50$ & 0.0075 & 0.53 & 0.0367 & 86039 & 422772 & 2426407 & 28.20 & 25.87 & 30.54 \\
\hline $50-55$ & 0.0110 & 0.53 & 0.0537 & 82881 & 403952 & 2003635 & 24.17 & 22.01 & 26.34 \\
\hline $55-60$ & 0.0149 & 0.52 & 0.0720 & 78434 & 378617 & 1599683 & 20.40 & 18.43 & 22.36 \\
\hline $60-65$ & 0.0220 & 0.52 & 0.1047 & 72787 & 345648 & 1221066 & 16.78 & 15.02 & 18.54 \\
\hline $65-69$ & 0.0251 & 0.51 & 0.1180 & 65167 & 306990 & 875418 & 13.43 & 11.91 & 14.96 \\
\hline $70-74$ & 0.0488 & 0.52 & 0.2185 & 57475 & 257231 & 568428 & 9.89 & 8.56 & 11.22 \\
\hline $75-79$ & 0.0914 & 0.51 & 0.3734 & 44915 & 183487 & 311197 & 6.93 & 5.80 & 8.06 \\
\hline $80-84$ & 0.1633 & 0.50 & 0.5798 & 28144 & 99922 & 127711 & 4.54 & 3.65 & 5.42 \\
\hline $85+$ & 0.2180 & 0.47 & 1.0000 & 11825 & 27788 & 27788 & 2.35 & 2.35 & 2.35 \\
\hline $\begin{array}{c}\text { Female } \\
\text { Age interval }\end{array}$ & Death & $\begin{array}{l}\text { Fraction } \\
\text { of last age }\end{array}$ & $\begin{array}{l}\text { Probability } \\
\text { of dying }\end{array}$ & $\begin{array}{l}\text { No of living } \\
\text { at age } \\
\text { interval }\end{array}$ & $\begin{array}{l}\text { Number of } \\
\text { Yrs Lived }\end{array}$ & $\begin{array}{l}\text { Total No. of } \\
\text { Yrs Lived } \\
\text { beyond }\end{array}$ & $\begin{array}{l}\text { Expectation } \\
\text { of life }\end{array}$ & $95 \% \mathrm{Co}$ & ce Limits \\
\hline $\begin{array}{l}\text { (in years) } \\
x \text { to } x+1\end{array}$ & $\begin{array}{c}\text { Rate } \\
\text { Mi }\end{array}$ & $\begin{array}{c}\text { interval } \\
\text { ai }\end{array}$ & $\begin{array}{c}\text { in interval } \\
\text { qi }\end{array}$ & $\begin{array}{c}\text { of life } \\
\text { li }\end{array}$ & $\begin{array}{c}\text { in interval } \\
\mathrm{Li}\end{array}$ & $\begin{array}{c}\text { age } x_{i} \\
T i\end{array}$ & $\begin{array}{c}\text { at age } x_{i} \\
\text { ei }\end{array}$ & $\begin{array}{c}\text { Lower } \\
\text { Limit }\end{array}$ & $\begin{array}{l}\text { Upper } \\
\text { Limit }\end{array}$ \\
\hline $1-5$ & 0.0015 & 0.41 & 0.0061 & 99008 & 394608 & 7197338 & 72.69 & 69.42 & 75.97 \\
\hline $5-10$ & 0.0003 & 0.44 & 0.0016 & 98404 & 491591 & 6802730 & 69.13 & 66.02 & 72.24 \\
\hline $10-15$ & 0.0005 & 0.54 & 0.0027 & 98251 & 490638 & 6311139 & 64.24 & 61.17 & 67.30 \\
\hline $15-20$ & 0.0012 & 0.59 & 0.0060 & 97983 & 488716 & 5820501 & 59.40 & 56.39 & 62.41 \\
\hline $20-25$ & 0.0014 & 0.49 & 0.0069 & 97398 & 485277 & 5331786 & 54.74 & 51.84 & 57.64 \\
\hline $25-30$ & 0.0014 & 0.51 & 0.0070 & 96726 & 481984 & 4846508 & 50.11 & 47.32 & 52.89 \\
\hline $30-35$ & 0.0024 & 0.52 & 0.0117 & 96054 & 477561 & 4364524 & 45.44 & 42.75 & 48.13 \\
\hline $35-40$ & 0.0032 & 0.53 & 0.0161 & 94926 & 471031 & 3886962 & 40.95 & 38.39 & 43.50 \\
\hline $40-45$ & 0.0043 & 0.54 & 0.0211 & 93395 & 462448 & 3415931 & 36.58 & 34.18 & 38.97 \\
\hline $45-50$ & 0.0049 & 0.53 & 0.0241 & 91427 & 451948 & 2953483 & 32.30 & 30.09 & 34.52 \\
\hline $50-55$ & 0.0072 & 0.53 & 0.0355 & 89220 & 438652 & 2501535 & 28.04 & 25.99 & 30.09 \\
\hline $55-60$ & 0.0094 & 0.52 & 0.0458 & 86051 & 420800 & 2062883 & 23.97 & 22.12 & 25.82 \\
\hline $60-65$ & 0.0162 & 0.52 & 0.0778 & 82112 & 395232 & 1642083 & 20.00 & 18.36 & 21.64 \\
\hline $65-69$ & 0.0113 & 0.51 & 0.0549 & 75725 & 368444 & 1246852 & 16.47 & 15.14 & 17.79 \\
\hline $70-74$ & 0.0236 & 0.52 & 0.1115 & 71569 & 338692 & 878408 & 12.27 & 11.12 & 13.43 \\
\hline $75-79$ & 0.0501 & 0.51 & 0.2229 & 63588 & 283209 & 539716 & 8.49 & 7.55 & 9.43 \\
\hline $80-84$ & 0.1145 & 0.50 & 0.4451 & 49412 & 192074 & 256506 & 5.19 & 4.52 & 5.86 \\
\hline $85+$ & 0.2252 & 0.47 & 1.0000 & 27418 & 64432 & 64432 & 2.35 & 2.35 & 2.35 \\
\hline
\end{tabular}

Note: Western Region: N.W.T., Saskatchewan, Alberta, Yukon, and B.C.

Source: Development \& Demographic Methods Section, Demography Division, Statistics Canada, 2003. 